\title{
Deciduoid mesothelioma: report of 21 cases with review of the literature
}

\author{
Nelson G Ordóñez
}

Department of Pathology, The University of Texas MD Anderson Cancer Center, Houston, TX, USA

\begin{abstract}
Deciduoid mesothelioma is a rare variant of epithelioid mesothelioma that was initially considered to occur exclusively in the peritoneum of young women who had no history of asbestos exposure and to be characterized by an aggressive clinical course, but it was later demonstrated that this tumor could also occur in the pleura of older men and women who had been exposed to asbestos. Some subsequent studies have also indicated that the clinical course is no different from that of conventional epithelioid mesothelioma. Herein are reported 21 cases of deciduoid mesothelioma that were investigated using a large panel of immunohistochemical markers, 9 of which were also studied by electron microscopy. Fifteen of the patients were male and 6 were female (mean age, 60 years). Seventeen of the cases originated in the pleura and four in the peritoneum. Histologically, all of the cases were composed of large, polygonal or ovoid cells with well-defined cell borders, dense eosinophilic cytoplasm, and single or multiple nuclei. In some cases, the cells exhibited a wide variation in their size and shape, frequent loss of cell cohesion, marked nuclear atypia, and high mitotic activity ( $>5$ per 10 HPF); whereas, in others, the cells were more cohesive, less pleomorphic, and the mitotic activity low. As the survival of patients in the first group of cases was shorter (mean, 7 months), when compared with that of the latter (mean, 23 months), it is concluded that the differences in prognosis reported in deciduoid mesothelioma are due to the existence of a high-grade subgroup that presents highly aggressive clinical behavior. Therefore, when a high-grade deciduoid mesothelioma is present, it should be reported as it can significantly affect prognosis and treatment. The use of immunohistochemistry and electron microscopy in assisting in the differential diagnosis of deciduoid mesothelioma is also discussed.
\end{abstract}

Modern Pathology (2012) 25, 1481-1495; doi:10.1038/modpathol.2012.105; published online 8 June 2012

Keywords: deciduoid mesothelioma; electron microscopy; immunohistochemistry

Deciduoid mesothelioma is the term used for an uncommon subtype of epithelioid mesothelioma that is characterized by the presence of cytomorphological features resembling decidua or decidualized tissue. ${ }^{1}$ In 1985, Talerman et $a l^{2}$ reported the first case of this mesothelioma variant, which arose in the peritoneum of a 13-year-old girl who had initially been diagnosed as having diffuse pseudotumoral deciduosis. The patient died 8 months after diagnosis. In 1994, Nascimento et al ${ }^{1}$ reported two additional cases of a similar type of mesothelioma also arising in the peritoneum in two women, 23 and 24 years of age, respectively. In the one case in which follow-up information was available, the patient died of disease 4 months after diagnosis.

Correspondence: Dr NG Ordóñez, MD, Department of Pathology, The University of Texas MD Anderson Cancer Center, 1515 Holcombe Boulevard, Houston, TX 77030, USA.

E-mail: nordonez@mdanderson.org

Received 17 March 2012; revised 19 April 2012; accepted 19 April 2012; published online 8 June 2012
Five years later, Orosz et $a l^{3}$ reported a fourth case of a deciduoid peritoneal mesothelioma in a 15-yearold girl who died of disease 11 months after diagnosis. As all four of the previously mentioned cases originated in the peritoneum and occurred in women with no known history of asbestos exposure, it was suggested that deciduoid mesothelioma was a unique clinicopathological variant of peritoneal mesothelioma that affects young women and is characterized by aggressive clinical behavior. In 2000, six additional cases were reported by Shanks et $a l^{4}$ and four more by Ordóñez. ${ }^{5}$ In these reports, however, it was demonstrated that mesotheliomas with deciduoid features can also originate in the pleura, occur in elderly men, and be associated with asbestos exposure. Since then, several other cases, mostly individual case reports, have been published $^{6-24}$ (Table 1). Although patient survival in many of the published cases has been short and limited to a few months after diagnosis, thus suggesting that deciduoid mesotheliomas have an aggressive clinical course, patients with long survival 
Table 1 Summary of published cases of deciduoid mesothelioma

\begin{tabular}{|c|c|c|c|c|c|c|c|}
\hline Author(s) & Sex/age & $\begin{array}{l}\text { Asbestos } \\
\text { exposure }\end{array}$ & Location & Type of specimen & Histology & Treatment & $\begin{array}{l}\text { Follow-up } \\
\text { (months) }\end{array}$ \\
\hline Talerman et $a l^{2}$ & $\mathrm{~F} / 13$ & No & Peritoneum & Peritoneal biopsies & $\begin{array}{l}\text { Undifferentiated polygonal cells arranged in a } \\
\text { sheet-like pattern. High mitotic activity present, } \\
\text { including atypical forms }\end{array}$ & Chemotherapy & DOD (8) \\
\hline \multirow[t]{2}{*}{ Nacimento et al ${ }^{1}$} & $\mathrm{~F} / 23$ & No & Peritoneum & Peritoneal biopsies & Deciduoid & INA & DOD (4) \\
\hline & $\mathrm{F} / 24$ & No & Peritoneum & Peritoneal biopsies & Deciduoid & INA & INA \\
\hline Orosz et $a l^{3}$ & $\mathrm{~F} / 15$ & No & Peritoneum & Peritoneal biopsy & $\begin{array}{l}\text { Large polygonal or ovoid cells arranged in solid } \\
\text { sheets or trabeculae. Binucleated cells present. } \\
\text { Ten to } 15 \text { mitoses per } 10 \mathrm{HPF} \text {, including atypical }\end{array}$ & $\begin{array}{l}\text { Chemotherapy + } \\
\text { radiotherapy }\end{array}$ & DOD (11) \\
\hline \multirow[t]{6}{*}{ Shanks et $a l^{4}$} & $\mathrm{M} / 59$ & No & $\begin{array}{l}\text { Paratesticular, } \\
\text { spermatic cord }\end{array}$ & Orchiectomy, autopsy & $\begin{array}{l}\text { Deciduoid with occasional tubulopapillary or } \\
\text { acinar areas }\end{array}$ & $\begin{array}{l}\text { Orchiectomy + } \\
\text { chemotherapy }\end{array}$ & DOD (4) \\
\hline & $\mathrm{F} / 53$ & Yes & Peritoneum & Peritoneal biopsies & Deciduoid & Symptomatic & DOD (9) \\
\hline & $\mathrm{M} / 65$ & Yes & Peritoneum & Biopsy + autopsy & Deciduoid & Tumor resection & DOD (4) \\
\hline & $\mathrm{M} / 55$ & Yes & Peritoneum & Tumor resection & $\begin{array}{l}\text { Deciduoid with tubular and sarcomatoid areas. } \\
\text { Multi-nucleated cells and mitoses, including } \\
\text { atypical }\end{array}$ & Tumor debulking & AWD (60) \\
\hline & $\mathrm{F} / 55$ & No & Peritoneum & Peritoneal biopsies & $\begin{array}{l}\text { Predominantly tubulopapillary with focal } \\
\text { sarcomatoid areas and scattered small groups of } \\
\text { deciduoid cells }\end{array}$ & $\begin{array}{l}\text { Hysterectomy with } \\
\text { bilateral salpingo- } \\
\text { ooforectomy }\end{array}$ & DOD (4) \\
\hline & $\mathrm{M} / 52$ & Yes & Pleura & Pleural biopsies & Deciduoid with tubulopapillary areas & Symptomatic & AWD (8) \\
\hline \multirow[t]{4}{*}{ Ordóñez ${ }^{5}$} & $\mathrm{~F} / 46$ & No & Pleura & Pneumonectomy & $\begin{array}{l}\text { Large polygonal or ovoid cells arranged in sheets } \\
\text { or trabeculae. Three to five mitoses per } 10 \mathrm{HPF}\end{array}$ & Pneumonectomy & DOD (6) \\
\hline & $\mathrm{M} / 64$ & Yes & Pleura & Pneumonectomy & $\begin{array}{l}\text { Sheets of large cells with abundant dense } \\
\text { cytoplasm. Two to four mitoses per } 10 \mathrm{HPF}\end{array}$ & $\begin{array}{l}\text { Chemotherapy }+ \\
\text { pneumonectomy }\end{array}$ & DOD (8) \\
\hline & $\mathrm{M} / 60$ & No & Pleura & Pneumonectomy & $\begin{array}{l}\text { Solid sheets of large cells with dense } \\
\text { eosinophilic cytoplasm and deciduoid features. } \\
\text { Mitotic figures were not uncommon }\end{array}$ & $\begin{array}{l}\text { Pneumonectomy + } \\
\text { radiation }\end{array}$ & DOD (5) \\
\hline & $\mathrm{M} / 78$ & Yes & Pleura & Pleural fluid & $\begin{array}{l}\text { Large polygonal cells with abundant eosinophilic } \\
\text { cytoplasm }\end{array}$ & INA & INA \\
\hline $\begin{array}{l}\text { Gloeckner- } \\
\text { Hofmann et } a l^{6}\end{array}$ & $\mathrm{~F} / 40$ & No & Pleura & $\begin{array}{l}\text { Pleural biopsy + tumor } \\
\text { resection }\end{array}$ & Deciduoid & Chemotherapy & DOD \\
\hline Puttagunta et $a l^{7}$ & $\mathrm{M} / 41$ & No & Pleura & Pleural biopsy & Deciduoid with rhabdoid change & Radiotherapy & DOD (21) \\
\hline Desai et $a l^{8}$ & $\mathrm{~F} / 53$ & INA & Peritoneum & Tumor resection & $\begin{array}{l}\text { Giant cells with abundant eosinophilic } \\
\text { cytoplasm and sharp borders. Nuclear } \\
\text { pleomorphism with hyperchromasia and } \\
\text { prominent nucleoli }\end{array}$ & $\begin{array}{l}\text { Debulking + } \\
\text { hysterectomy with } \\
\text { bilateral salpingo- } \\
\text { oophorectomy }\end{array}$ & INA \\
\hline Gillespie et $a l^{9}$ & $\mathrm{~F} / 50$ & No & Peritoneum & Peritoneal fluid & $\begin{array}{l}\text { Deciduoid cells, some binucleated or multi- } \\
\text { nucleated. An occasional mitosis was seen }\end{array}$ & Chemotherapy & AWD (12) \\
\hline Henley et $a l^{10}$ & $\mathrm{~F} / 30$ & No & Pleura & INA & $\begin{array}{l}\text { Deciduoid with vacuolated Clear areas. Three } \\
\text { mitoses per } 10 \mathrm{HPF}\end{array}$ & $\begin{array}{l}\text { Surgical resection }+ \\
\text { chemotherapy }\end{array}$ & AWD (5) \\
\hline $\begin{array}{l}\text { Monaghan and } \\
\text { Al-Nafussi }{ }^{11}\end{array}$ & $\mathrm{M} / 66$ & Yes & Pleura & Pleural biopsies & $\begin{array}{l}\text { Large round, oval, and polygonal cells with } \\
\text { abundant eosinophilic cytoplasm. Focal } \\
\text { cytoplasmic vacuolization and rare mitoses }\end{array}$ & INA & INA \\
\hline Okonkwo et al ${ }^{12}$ & $\mathrm{~F} / 30$ & No & Peritoneum & Tumor resection & Deciduoid. One to three mitoses per $10 \mathrm{HPF}$ & Surgical resection & NED (20) \\
\hline Reis-Filho et $a l^{13}$ & $\mathrm{~F} / 71$ & No & Pericardium & FNA biopsy, autopsy & $\begin{array}{l}\text { Deciduoid with tubulopapillary areas. Two } \\
\text { mitoses per } 10 \text { HPF }\end{array}$ & Symptomatic & $\begin{array}{l}\mathrm{DOD}^{\mathrm{a}} \\
(48 \mathrm{~h})\end{array}$ \\
\hline \multirow[t]{2}{*}{ Serio et $a l^{14}$} & $\mathrm{~F} / 23^{\mathrm{b}}$ & No & Pleura & Pleural biopsy & $\begin{array}{l}\text { Deciduoid with focal tubulopapillary areas. Two } \\
\text { mitoses per } 10 \mathrm{HPF}\end{array}$ & Symptomatic & DOD (39) \\
\hline & $\mathrm{M} / 73$ & Yes & Pleura & Pleural biopsy & $\begin{array}{l}\text { Deciduoid with focal tubulopapillary areas. Two } \\
\text { mitoses per } 10 \mathrm{HPF}\end{array}$ & Chemotherapy & DOD (17) \\
\hline
\end{tabular}


Table 1 Continued

\begin{tabular}{|c|c|c|c|c|c|c|c|}
\hline Author(s) & Sex/age & $\begin{array}{l}\text { Asbestos } \\
\text { exposure }\end{array}$ & Location & Type of specimen & Histology & Treatment & $\begin{array}{l}\text { Follow-up } \\
\text { (months) }\end{array}$ \\
\hline \multirow[t]{5}{*}{ Shia et $a 1^{15}$} & $\mathrm{~F} / 69$ & INA & Pleura & Pleurectomy specimen & Deciduoid & $\begin{array}{l}\text { Lobectomy + } \\
\text { pleurectomy }\end{array}$ & DOD (17) \\
\hline & $\mathrm{F} / 51$ & INA & Peritoneum & Tumor resection & $\begin{array}{l}\text { Deciduoid + tubulopapillary }(<25 \%) \text {. Some } \\
\text { deciduoid cells had pale or clear cytoplasm }\end{array}$ & Tumor debulking & DOD (1) \\
\hline & $\mathrm{F} / 71$ & No & Pleura & Decortication & Deciduoid & Decortication & DOD (4) \\
\hline & $\mathrm{M} / 65$ & Yes & Pleura & Pneumonectomy & Deciduoid & $\begin{array}{l}\text { Pneumonectomy + } \\
\text { radiation }\end{array}$ & NED (12) \\
\hline & $\mathrm{M} / 56$ & Yes & Peritoneum & Resected specimen & Deciduoid + tubulopapillary $(<5 \%)$ & $\begin{array}{l}\text { Tumor debulking + } \\
\text { chemotherapy }\end{array}$ & DOD (4) \\
\hline Chung et $a l^{16}$ & $\mathrm{~F} / 47$ & No & Peritoneum & Resected tumor & Deciduoid & $\begin{array}{l}\text { Tumor debulking + } \\
\text { chemotherapy }\end{array}$ & AWD (1) \\
\hline Asioli et $a l^{17}$ & $\mathrm{M} / 62$ & No & $\begin{array}{l}\text { Pleura, } \\
\text { predominantly } \\
\text { intrapulmonary } \\
\text { localized }\end{array}$ & Lobectomy & Deciduoid & Lt. upper lobectomy & AWD (20) \\
\hline Maeda et $a 1^{18}$ & $\mathrm{~F} / 24^{\mathrm{c}}$ & No & $\begin{array}{l}\text { Peritoneum } \\
\text { localized }\end{array}$ & Resected tumor & $\begin{array}{l}\text { Deciduoid. Intranuclear inclusions, some cells } \\
\text { were multinucleated and some had foamy } \\
\text { cytoplasm. Two to three mitoses per } 10 \mathrm{HPF}\end{array}$ & Resection & NED (32) \\
\hline $\begin{array}{l}\text { Mishra and } \\
\text { Shet }^{19}\end{array}$ & $\mathrm{M} / 75$ & No & $\begin{array}{l}\text { Paratesticular, } \\
\text { tunica vaginalis }\end{array}$ & Orchiectomy & $\begin{array}{l}\text { Predominantly composed of clear cells with focal } \\
\text { deciduoid and rhabdoid areas. Small areas of } \\
\text { tubulopapillary pattern present. Mitoses present }\end{array}$ & Orchiectomy & INA \\
\hline Kimura et $a l^{20}$ & $\mathrm{M} / 70$ & No & Peritoneum & $\begin{array}{l}\text { Peritoneal biopsy, } \\
\text { autopsy }\end{array}$ & $\begin{array}{l}\text { Deciduoid with irregular nuclei and some multi- } \\
\text { nucleated cells. Prominent mucinous stroma }\end{array}$ & INA & DOD (12) \\
\hline Mourra et $a l^{21}$ & $\mathrm{~F} / 41^{\mathrm{d}}$ & No & Peritoneum & Tumor resection & $\begin{array}{l}\text { Deciduoid with pleomorphic nuclei and rare } \\
\text { mitoses }\end{array}$ & Tumor debulking & DOD (14) \\
\hline \multirow[t]{6}{*}{ Scattone et $a l^{22}$} & $\mathrm{~F} / 23$ & Yes & Pleura & INA & Deciduoid & Palliative & DOD (39) \\
\hline & $\mathrm{M} / 73$ & Yes & Pleura & INA & Deciduoid & Chemotherapy & DOD (43) \\
\hline & $\mathrm{M} / 71$ & Yes & Pleura & INA & Deciduoid & Chemotherapy & DOD (38) \\
\hline & $\mathrm{F} / 32$ & Yes & Pleura & INA & Deciduoid & Palliative & DOD (24) \\
\hline & $\mathrm{F} / 52$ & Yes & Pleura & INA & Deciduoid & Chemotherapy & DOD (24) \\
\hline & $\mathrm{M} / 74$ & Yes & Pleura & INA & Deciduoid & Chemotherapy & DOD (12) \\
\hline Tsai et $a l^{23}$ & $\mathrm{M} / 13$ & No & Pleura & Pleural biopsy & $\begin{array}{l}\text { Deciduoid with binucleated and multinucleated } \\
\text { cells }\end{array}$ & $\begin{array}{l}\text { Chemotherapy }+ \\
\text { pneumonectomy }+ \\
\text { chemotherapy }\end{array}$ & AWD (24) \\
\hline Ustun et $a l^{24}$ & $\mathrm{~F} / 59$ & No & Peritoneum & FNA, tumor resection & $\begin{array}{l}\text { Deciduoid with occasional binucleated and } \\
\text { multinucleated cells. Pseudonuclear inclusions } \\
\text { and a few mitoses were seen }\end{array}$ & Resections & NED (3) \\
\hline
\end{tabular}

Abbreviations: AWD, alive with disease; DOD, died of disease; FNA, fine needle aspiration; INA, information not available; NED, no evidence of disease.

3. ${ }^{\mathrm{a}}$ Patient died $48 \mathrm{~h}$ after diagnosis, but had symptoms related to the disease for 8 months.

bamily history of mesothelioma.

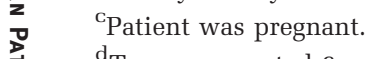

d Tumor presented 6 months after caesarean section and was initially misinterpreted as pseudotumoral deciduosis. 
have also been documented in the literature and, because of this, some authors have indicated that the deciduoid mesothelioma subtype does not appear to represent an unfavorable diagnostic category. ${ }^{14,15}$ In order to resolve these differences in opinion and to fully determine whether or not deciduoid mesothelioma should be regarded as a high grade subtype of epithelioid mesothelioma that carries a very poor prognosis, the clinical and pathology findings in 21 cases of this mesothelioma variant are herein reported. A detailed review and comparison with all other previously published cases is also provided.

\section{Materials and methods}

Twenty-one cases of epithelioid mesothelioma with deciduoid features were identified from a review of 650 mesothelioma cases from the files of the Department of Pathology at the University of Texas MD Anderson Cancer Center. The cases were selected based on at least $10 \%$ of the tumor being composed of large polygonal or ovoid cells having abundant, densely eosinophilic cytoplasm, vesicular nuclei with prominent nucleoli, and well-defined cell borders resembling decidua or decidualized tissue. Immunohistochemical studies were performed on formalinfixed, paraffin-embedded tissue specimens using the strepavidine-biotinylated peroxidase complex method in a Dako AutoStainer (Carpinteria, CA, USA). The primary antibodies are listed in Table 2. The immunostaining was carried out using the LSAB2 peroxidase kit (Dako). To enhance the immunostaining, a heat epitope retrieval procedure was performed using a Black-and-Decker vegetable steamer (Shelton, CT, USA) as previously described. ${ }^{25}$ The antigen-antibody immunoreaction was visualized using either 3-amino-9-ethylcarbazole or 3,3'diaminobenzidine as chromogen. To evaluate the specificity of the immunoreaction, known positive and negative tissues were used as controls. The immunostaining was graded on a sliding scale of $1+$ to $4+$ according to the percentage of reactive cells (trace, $<1 \%$; $1+$, 1-25\%; $2+, 26-50 \%$; $3+$, $51-75 \%$; $4+,>75 \%)$. For ultrastructural studies, samples of the tumor were fixed in $2 \%$ glutaraldehyde in phosphate buffer, post-fixed in $1 \%$ osmium tetroxide, and embedded in epon epoxy resin. Ultra-thin sections were stained with uranyl acetate and lead citrate.

\section{Results}

\section{Clinical Findings}

Fifteen patients were men and 6 were women, ranging in age from 39 to 78 years (mean, 60 years). There was a history of asbestos exposure in 11 patients and smoking in 10 . In 17 cases, the tumor originated in the pleura and in 4, in the peritoneum. Treatment information was available in only 19 of the patients, 17 of whom had pleural mesothelioma, and 2 peritoneal. Twelve of the patients with pleural mesothelioma underwent extrapleural pneumonectomy and most also received radiotherapy either alone or in combination with chemotherapy after surgery. One of the patients with peritoneal mesothelioma underwent tumor debulking followed by chemotherapy; whereas, the remaining one was treated with chemotherapy alone. Of the 17 patients for whom follow-up information was available, 16 died of disease 4-62 months after diagnosis (mean, 15 months) and 1 is alive with recurrent disease 25 months after extrapleural pneumonectomy.

\section{Pathology Findings}

Gross examination of the 12-pneumonectomy specimens showed diffuse involvement of the visceral and parietal pleura with encasement of the lung. Two patients had involvement of the adjacent lung parenchyma (cases 8 and 20); one each of the pericardium alone (case 7), and diaphragm alone (case 6); diaphragm and chest wall (case 9); lung, diaphragm and chest wall (case 12); and pericardium, diaphragm, chest wall, and adjacent lung parenchyma (case 1). Multiple lymph nodes were involved by metastases in 10 of the cases (cases 2, 4, 6, 8, 9, 12, 13, 18, 20, and 21). The most significant microscopic findings are summarized in Table 3. Histologically,

Table 2 Antibodies used in this study

\begin{tabular}{|c|c|c|c|c|}
\hline Marker & Source & Type & Dilution & Antigen retrieval \\
\hline Calretinin & Zymed (South San Francisco, CA, USA) & PAb (rabbit) & $1: 20$ & Yes (citrate) \\
\hline Pan-keratin & Dako Corporation (Carpinteria, CA, USA) & AE1/AE3 MAbs & $1: 50$ & Yes (citrate) \\
\hline Keratin 7 & Dako Corporation & OV-TL $12 / 30$ & $1: 100$ & Yes (enzymatic digestion) \\
\hline Keratin 5/6 & Dako Corporation & $\mathrm{D} 5 / 16 \mathrm{~B} 4 \mathrm{MAb}$ & $1: 100$ & Yes (citrate) \\
\hline Podoplanin & Signet Laboratories (Dedham, MA, USA) & $\mathrm{D} 2-40 \mathrm{MAb}$ & $1: 25$ & Yes (Tris-EDTA) \\
\hline WT1 & Dako Corporation & $6 \mathrm{~F}-\mathrm{H} 2 \mathrm{MAb}$ & $1: 40$ & Yes (Tris-EDTA) \\
\hline Mesothelin & Novocastra (Newcastle-upon-Tyne, UK) & $5 \mathrm{~B} 2$ & $1: 30$ & Yes (Tris-EDTA) \\
\hline MOC-31 & Dako Corporation & MAb & $1: 50$ & Yes (citrate) \\
\hline CEA & Lab Vision (Fremont, CA, USA) & PAb (rabbit) & $1: 200$ & No \\
\hline CD15 & Becton-Dickinson (Mountain view, CA, USA) & Leu-M1 MAb & $1: 40$ & Yes (Tris-EDTA) \\
\hline TAG-72 & BioGenex (San Ramon, CA, USA) & B72.3 MAb & $1: 300$ & No \\
\hline TTF-1 & Dako Corporation & 8G7G3/1 MAb & $1: 25$ & Yes (citrate) \\
\hline HCG & Sigma-Aldrich (St Louis, MO, USA) & PAb (rabbit) & $1: 1400$ & No \\
\hline
\end{tabular}


Table 3 Summary of clinical and pathological findings

\begin{tabular}{|c|c|c|c|c|c|c|c|}
\hline Case & Sex/age & $\begin{array}{l}\text { Asbestos } \\
\text { exposure }\end{array}$ & Location & $\begin{array}{l}\text { Type of } \\
\text { specimen }\end{array}$ & Light microscopy & Treatment & $\begin{array}{l}\text { Follow-up } \\
\text { (months) }\end{array}$ \\
\hline 1 & $\mathrm{~F} / 46$ & No & Pleura & Pneumonectomy & $\begin{array}{l}\text { Deciduoid with focal }(5-10 \%) \text { papillary. Ten to } 15 \text { mitoses per } 10 \\
\text { HPF, often atypical. Multi-nucleated cells and nuclear } \\
\text { pseudoinclusions were often seen. Necrosis and inflammation } \\
\text { present }\end{array}$ & Pneumonectomy & DOD (6) \\
\hline 2 & $\mathrm{M} / 60$ & No & Rt. pleura & Pneumonectomy & $\begin{array}{l}\text { Solid sheets of large deciduoid cells, sometimes with } \\
\text { intracytoplasmic lumens. Mitoses were common (5-10 per } 10 \mathrm{HPF})\end{array}$ & $\begin{array}{l}\text { Pneumonectomy + } \\
\text { radiotherapy }\end{array}$ & DOD (5) \\
\hline 3 & $\mathrm{M} / 78$ & No & $\begin{array}{l}\text { Peritoneum } \\
\text { (Rt. groin) }\end{array}$ & Biopsy & $\begin{array}{l}\text { Solid sheets of large, deciduoid cells. Combined with medium- sized } \\
\text { cuboidal cells arranged in a solid pattern. Mitoses were rare }\end{array}$ & INA & INA \\
\hline 4 & $\mathrm{M} / 57$ & Yes & Rt. pleura & Pneumonectomy & $\begin{array}{l}\text { About } 20 \% \text { composed of large cells with dense eosinophilic } \\
\text { cytoplasm. One to two mitoses per } 10 \mathrm{HPF}\end{array}$ & $\begin{array}{l}\text { Pneumonectomy + } \\
\text { radiotherapy }\end{array}$ & AWD (25) \\
\hline 5 & $\mathrm{M} / 62$ & No & Peritoneum & Peritoneal nodules & $\begin{array}{l}\text { Diffuse solid sheets of epithelial cells with deciduoid features and } \\
\text { Extensive necrosis. Zero to two mitoses per } 10 \mathrm{HPF}\end{array}$ & Debulkiing + chemotherapy & DOD (6) \\
\hline 6 & $\mathrm{M} / 71$ & Yes & Lt. pleura & Pneumonectomy & $\begin{array}{l}\text { Twenty percent of the tumor composed of large epithelioid cells, } \\
\text { often multinucleated, with deciduoid features. Mitotic activity was } \\
\text { high ( }>5 \text { per } 10 \mathrm{HPF})\end{array}$ & $\begin{array}{l}\text { Pneumonectomy + } \\
\text { radiotherapy }\end{array}$ & DOD (4) \\
\hline 7 & $\mathrm{M} / 50$ & Yes & Rt. pleura & Pneumonectomy & $\begin{array}{l}\text { Biphasic. About } 20 \% \text { deciduoid with abundant binucleated and } \\
\text { multinucleated cells. Mitotic activity high ( }>5 \text { per } 10 \mathrm{HPF})\end{array}$ & Pneumonectomy & DOD (6) \\
\hline 8 & $\mathrm{M} / 74$ & Yes & Lt. pleura & Pneumonectomy & $\begin{array}{l}\text { About } 80 \% \text { of the tumor is composed of large, often multinucleated, } \\
\text { epithelioid cells. High mitotic activity ( }>5 \text { per } 10 \mathrm{HPF} \text { ). Extensive } \\
\text { necrosis and prominent lymphatic invasion }\end{array}$ & $\begin{array}{l}\text { Pneumonectomy + } \\
\text { radiotherapy }\end{array}$ & DOD (17) \\
\hline 9 & $\mathrm{M} / 43$ & Yes & Rt. pleura & Pneumonectomy & $\begin{array}{l}\text { About } 60 \% \text { of the tumor composed of large cells with glassy } \\
\text { cytoplasm. Two to three mitoses per } 10 \mathrm{HPF}\end{array}$ & $\begin{array}{l}\text { Pneumonectomy }+ \\
\text { radiotherapy + chemotherapy }\end{array}$ & INA \\
\hline 10 & $\mathrm{M} / 61$ & Yes & Lt. pleura & Pleural biopsy & $\begin{array}{l}\text { Large cells with deciduoid features. Low mitotic activity (1 per } 10 \\
\text { HPF) }\end{array}$ & Symptomatic & INA \\
\hline 11 & $\mathrm{M} / 56$ & No & Peritoneum & Biopsy & $\begin{array}{l}\text { Diffuse proliferation of large epithelioid cells, some of which are } \\
\text { multinucleated. Numerous mitoses, many atypical ( } 10 \text { per } 10 \mathrm{HPF})\end{array}$ & INA & INA \\
\hline 12 & $\mathrm{~F} / 51$ & Yes & Rt. pleura & Pneumonectomy & $\begin{array}{l}\text { About } 30 \% \text { composed of large cells with glassy cytoplasm. Multi- } \\
\text { nucleated cells present. Moderate mitotic activity present ( } 3-5 \text { per } 10 \\
\text { HPF) }\end{array}$ & $\begin{array}{l}\text { Pneumonectomy }+ \\
\text { radiotherapy + chemotherapy }\end{array}$ & DOD (18) \\
\hline 13 & $\mathrm{M} / 73$ & Yes & Rt. pleura & Pneumonectomy & $\begin{array}{l}\text { About } 20 \% \text { deciduoid with focal clear cells. Multinucleated cells } \\
\text { and high mitotic activity ( }>5 \text { per } 10 \mathrm{HPF})\end{array}$ & $\begin{array}{l}\text { Chemotherapy + } \\
\text { pneumonectomy }\end{array}$ & DOD (6) \\
\hline 14 & $\mathrm{~F} / 50$ & No & Rt. pleura & Pleurectomy & $\begin{array}{l}\text { About } 50 \% \text { of the tumor composed of diffuse proliferation of } \\
\text { epithelioid cells with deciduoid features. One to three mitoses per } 10 \\
\text { HPF }\end{array}$ & Chemotherapy & DOD (8) \\
\hline 15 & $\mathrm{M} / 62$ & Yes & Rt. pleura & Pleural biopsy & $\begin{array}{l}\text { Diffuse proliferation of large, discohesive cells, many of which are } \\
\text { multinucleated. Mitoses, including atypical, were numerous ( }>5 \text { per } \\
10 \mathrm{HPF} \text { ) }\end{array}$ & Chemotherapy & DOD (4) \\
\hline 16 & $\mathrm{~F} / 39$ & No & Peritoneum & Biopsy & $\begin{array}{l}\text { Diffuse proliferation of large neoplastic cells with deciduoid features. } \\
\text { Mitoses were rare ( } 0-1 \text { per } 10 \mathrm{HPF})\end{array}$ & Chemotherapy & DOD (20) \\
\hline 17 & $\mathrm{M} / 66$ & No & Lt. pleura & Pleurectomy & $\begin{array}{l}\text { About } 40 \% \text { of the tumor composed of a diffuse proliferation of large } \\
\text { neoplastic cells with glassy cytoplasm. Mitoses were rare }(<1 \text { per } 10 \\
\text { HPF })\end{array}$ & Pleurectomy + chemotherapy & DOD (62) \\
\hline 18 & $\mathrm{M} / 61$ & Yes & Pleura & Pneumonectomy & $\begin{array}{l}\text { Fifty percent deciduoid, } 85 \% \text { tubulopapillary. One to three mitoses } \\
\text { per } 10 \mathrm{HPF}\end{array}$ & $\begin{array}{l}\text { Pneumonectomy + } \\
\text { radiotherapy }\end{array}$ & DOD (6) \\
\hline 19 & $\mathrm{M} / 67$ & Yes & Rt. pleura & Decortication & $\begin{array}{l}\text { Deciduoid with prominent myxoid stroma. Few binucleated and } \\
\text { multinucleated tumor cells present. Mitotic figures were rare }(0-1 \\
\text { per } 10 \mathrm{HPF})\end{array}$ & $\begin{array}{l}\text { Decortication and tumor } \\
\text { debulking + chemotherapy }\end{array}$ & DOD (19) \\
\hline 20 & $\mathrm{~F} / 56$ & No & Rt. pleura & Pneumonectomy & $\begin{array}{l}\text { Ten percent deciduoid with abundant signet- ring cells. Mitotic } \\
\text { figures were rare }(0-1 \text { per } 10 \mathrm{HPF})\end{array}$ & $\begin{array}{l}\text { Pneumonectomy + } \\
\text { radiotherapy }\end{array}$ & DOD (35) \\
\hline 21 & F/68 & No & Rt. pleura & Pneumonectomy & $\begin{array}{l}\text { Forty percent deciduoid with abundant signet- ring cells. } \\
\text { Multinucleated cells and mitotic figures were uncommon ( } 1-2 \text { per } 10 \\
\text { HPF) }\end{array}$ & $\begin{array}{l}\text { Pneumonectomy }+ \\
\text { chemotherapy }\end{array}$ & DOD (18) \\
\hline
\end{tabular}

Abbreviations: AWD, alive with disease; DOD, died of disease; INA, information not available. 
the tumor present in the biopsy material was entirely composed of a diffuse proliferation of neoplastic cells exhibiting deciduoid features; whereas, the proportion of the deciduoid component ranged from $15 \%$ to nearly $100 \%$ in the pneumonectomy specimens. Although in all cases, the deciduoid component appeared to be made of large epithelioid cells having well-defined borders and dense eosinophilic cytoplasm, some differences were observed between cases. The cells in some cases tended to be uniform in size (Figure 1a); while in others, a great variation in size and shape was seen (Figures 1b-d and 3c, f). Similarly, in some cases, the nuclei exhibited regular contours, evenly distributed chromatin, and a single nucleolus (Figure 1a); whereas, in others the nuclei were irregular, often had clumped chromatin, several nucleoli, and frequent nuclear pseudoinclusions (Figures 1c, 3d and 4a, c). In the latter cases, the cells were often discohesive and frequently contained a relatively large population of binucleated and multinucleated neoplastic cells. In addition, the mitotic activity in these cases was high ( $>5$ mitoses per 10 HPF) and atypical mitotic figures were often seen (Figure 1b). Although, in general, the neoplastic cells were arranged in solid nests, in one case, they appeared to be lining villous-like structures or irregular spaces that formed as a result of the loss of cohesion of the neoplastic cells (Figures 1e and f). Three of the cases (Cases 1, 6, and 13) showed focal areas in which the deciduoid cells had vacuolated and/or clear cytoplasm (Figures $1 \mathrm{~g}$ and h). PAS stains performed in these cases were negative for glycogen. In one of the cases (Case 7), the neoplastic cells became markedly discohesive and progressively pleomorphic with some of the cells exhibiting rhabdoid features (Figures 2a-c). Several of the tumors had sparse cells with intracytoplasmic lumina, but in one of the cases (Case 21), these cells were numerous and some exhibited a signet-ring-like morphology (Figures 2d-f). One of the cases (Case 19) had prominent myxoid stroma (Figures $2 \mathrm{~g}$ and $\mathrm{h}$ ).

\section{Immunohistochemistry}

The immunohistochemical results are summarized in Table 4. The neoplastic deciduoid cells in all 21 cases strongly reacted for calretinin and the staining was both nuclear and cytoplasmic (Figure 3a). They were also strongly positive for pankeratin, keratin 7 , keratin 5/6, and mesothelin in all cases stained for these markers (Figures $3 \mathrm{~b}$ and c). Thirteen (93\%) of
14 and 11 (85\%) of 13 cases were positive for podoplanin and WT1, respectively, and the staining was nuclear (WT1, Figure 3d) and along the cell membrane (podoplanin, Figures $3 e$ and f). All of the cases stained for MOC-31, CEA, TAG-72, CD15, TTF-1, or HCG were negative for these markers.

\section{Electron Microscopy Findings}

The ultrastructural features of all nine of the cases for which tissue was submitted for electron microscopic evaluation were very similar. The tumor cells often appeared discohesive and the cell membranes were covered by a large number of slender microvilli (Figure 4a). The nuclei were pleomorphic, single or multiple, exhibited markedly irregular contours, and contained one or more nucleoli (Figures 4a and b). On occasion, nuclear pseudoinclusions consisting of cytoplasm were seen (Figure 4c). The cytoplasm was abundant and contained a large number of intermediate filaments, often arranged in bundles (Figure 4b). In some of the cases, intracytoplasmic lumina were seen. The cell membrane lining the lumina was often covered by long microvilli (Figure 4e) and, on occasion, contained electron-dense material that most probably represented proteoglycans (Figure 4f).

\section{Discussion}

One of the main characteristics of the tumors arising from the serosal membranes is their ability to present a wide range of morphological features. Histologically, mesotheliomas have been classified into three major variants: epithelioid, sarcomatoid, and mixed or biphasic. Epithelioid mesotheliomas often present a tubulopapillary or solid pattern, but on occasion, may exhibit a wide variety of other morphological appearances, including adenoid cystic, ${ }^{26}$ signetring, ${ }^{27,28}$ rhabdoid,${ }^{29}$ oncocytoid,${ }^{30}$ clear cell, ${ }^{31,32}$ small cell, ${ }^{33,34}$ glomeruloid, ${ }^{35}$ pleomorphic, ${ }^{36,37}$ and deciduoid. ${ }^{1,5,15}$ The term deciduoid mesothelioma was introduced by Nascimento et $a l^{1}$ in 1994 to describe a rare variant of epithelioid mesothelioma that bears a morphological resemblance to decidua or decidualtype changes. As, in the early studies, these tumors were reported to be clinically highly aggressive and to occur in the peritoneum of adolescent girls or young women who had no history of asbestos exposure, it was initially suggested that this variant of mesothelioma represented a distinct clinicopathological type

Figure 1 Case 6. (a) The tumor is composed of rather uniform, large cohesive cells with abundant eosinophilic cytoplasm and welldefined cell borders. The nuclei are vesicular with mild pleomorphism. A few binucleated (upper middle) and one multinucleated cell (lower center) are seen. Case 12. (b) The tumor cells show a great variation in their size, multinucleation (upper center), and inflammation. Two atypical mitoses are seen. Case 1. (c) The neoplastic cells in this case exhibit a great variation in their size; the nuclei are markedly atypical and often have nuclear pseudoinclusions (left lower corner and inset). (d) The cells in this area of the tumor appear discohesive and pleomorphic, and some are elongated. (e) In this area, the neoplastic cells appear lining villous-like projections. (f) Low magnification of an area in which the tumor cells appear lining irregular spaces that formed as a result of the loss of cohesion of the neoplastic cells. (g) Tumor cells with deciduoid features showing partial vacuolization of the cytoplasm. Case 6. (h) Tumor cells showing a more advanced degree of cell vacuolization with clearing of the cytoplasm. 

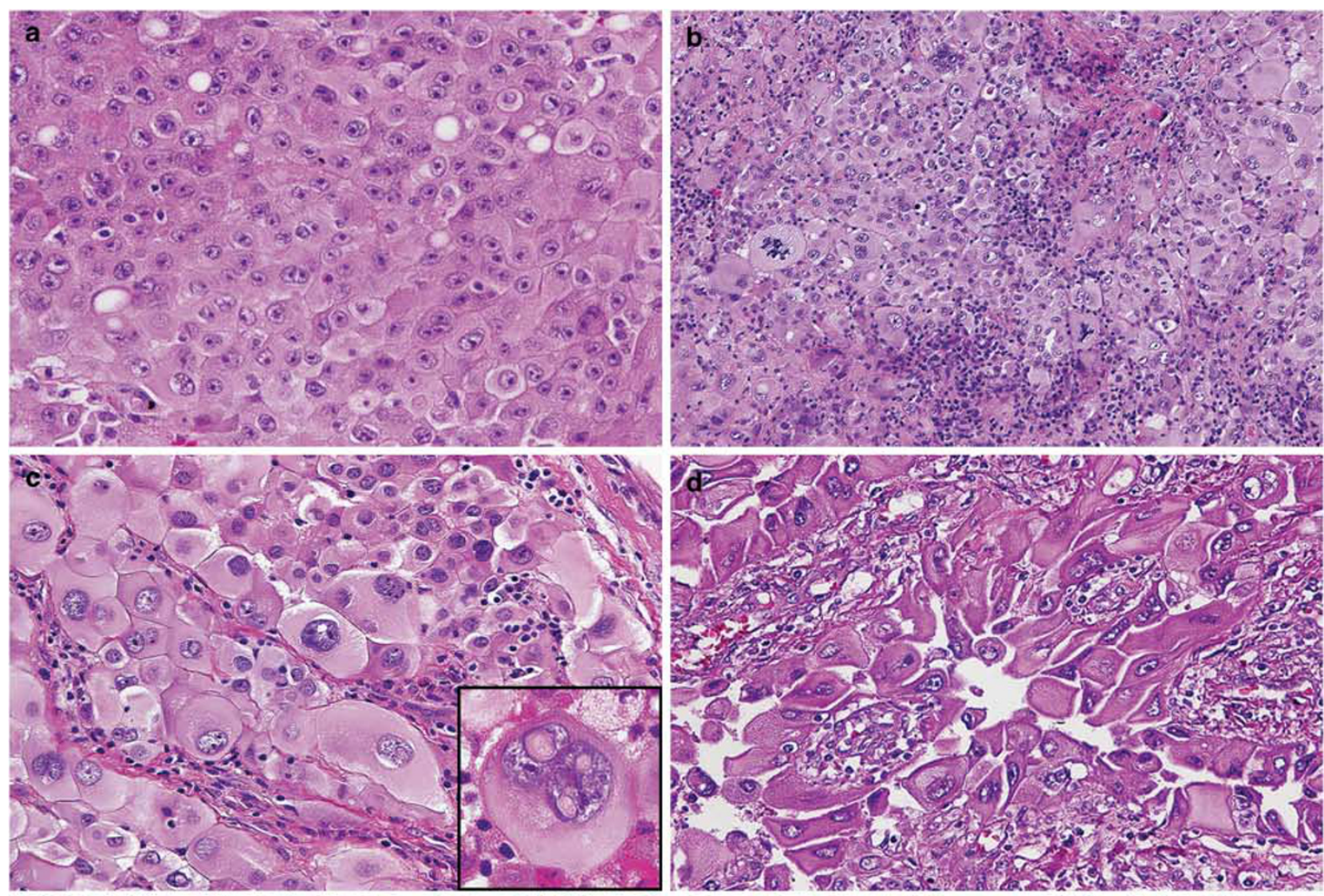

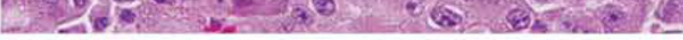
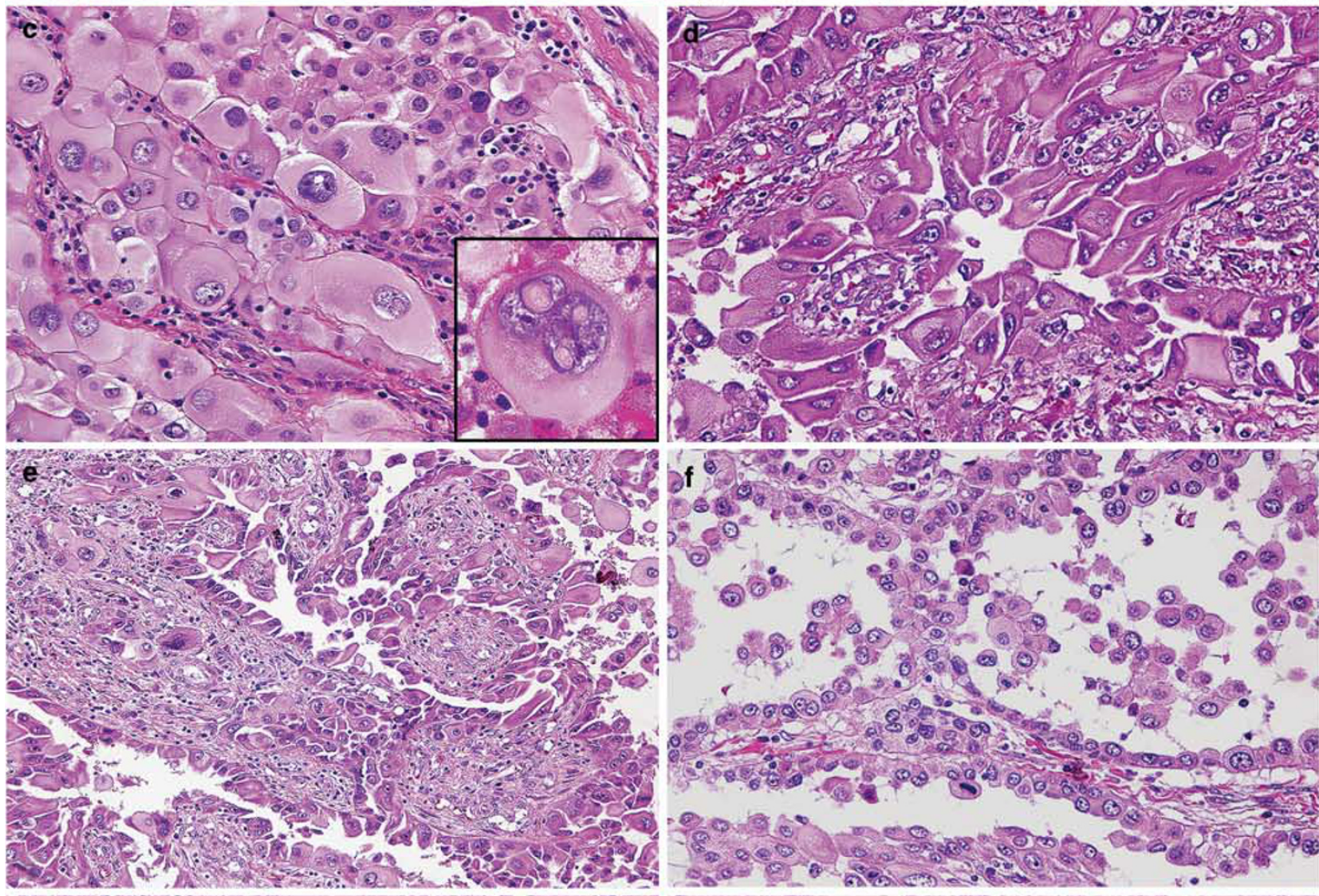
$f^{6}$ a

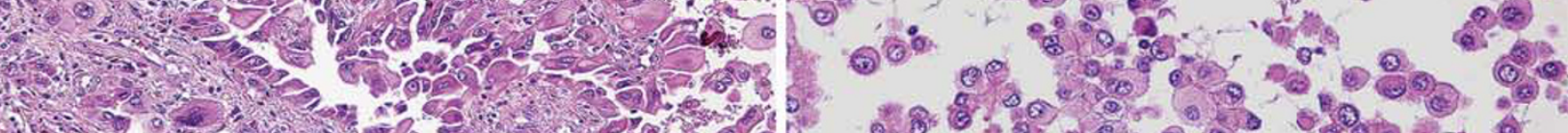

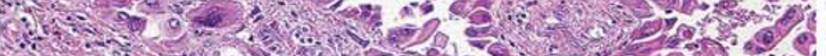
. a

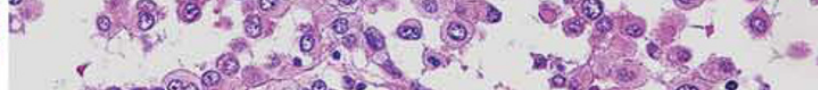

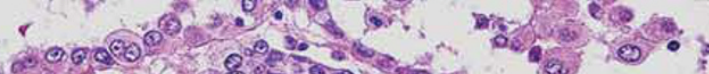

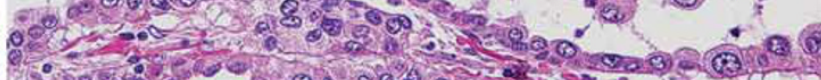

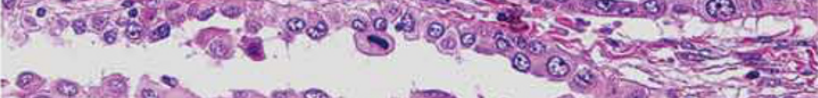

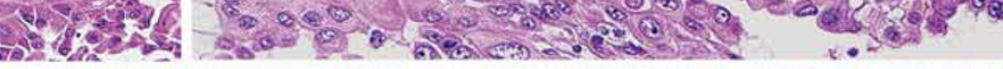

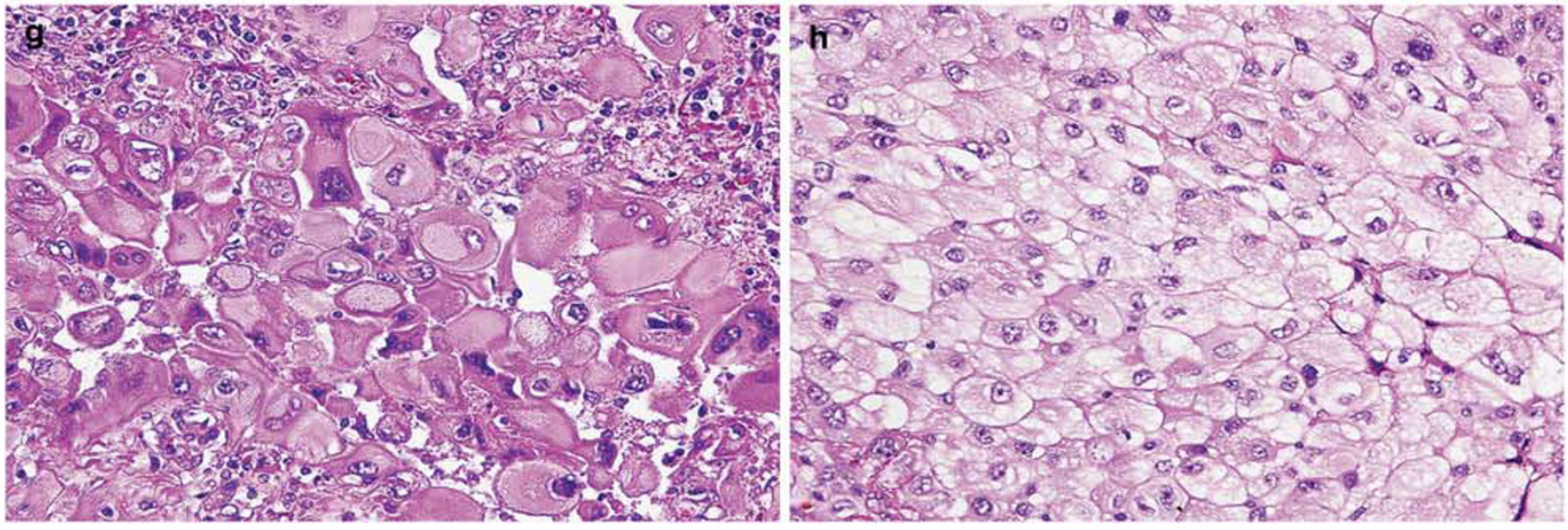


of mesothelioma. Subsequent investigations, however, have demonstrated that deciduoid mesotheliomas are not restricted to the peritoneum of young women, but can also arise in the pleura of older men and women who have a history of asbestos exposure, ${ }^{4,5}$ and these tumors may also have a less aggressive clinical course than was first reported. ${ }^{14}$

Of the 64 cases of deciduoid mesothelioma, including the 43 reported in the literature (Table 1) and the 21 in the present series (Table 3), 34 occurred in males who ranged in age from 13 to 78 years (mean, 62 years) and 30 in females who ranged in age from 13 to 71 years (mean, 44 years). In 39 cases, the tumor originated in the pleura, 22 in the peritoneum, 1 in the pericardium, and 2 in the paratesticular region. Of the 27 patients who had a history of asbestos exposure, the mesothelioma arose in the pleura in 23 patients and in the peritoneum in 4. That 39 (61\%) of the 64 deciduoid mesotheliomas originated in the pleura, when compared with 22 (34\%) in the peritoneum, and that males were affected slightly more frequently than females does not support the common belief that deciduoid mesotheliomas occur more often in women and arise more frequently in the peritoneum. ${ }^{15}$

According to published reports, deciduoid mesotheliomas are composed of large, polygonal, round, or ovoid cells having well-defined cell borders, abundant eosinophilic, glassy cytoplasm, and round vesicular nuclei presenting prominent nucleoli. ${ }^{8,24}$ Additionally, nuclear pleomorphism, nuclear pseudoinclusions, ${ }^{8,18,24}$ and binucleated or multinucleated cells have also been mentioned as being present in some of the reported cases. ${ }^{8,9,23,24}$ Mitotic activity has been documented as being variable and, although some reports have mentioned that the tumor had high mitotic activity and the presence of atypical mitoses,${ }^{2-5,8}$ others have indicated that only rare or few mitoses were present. ${ }^{11,13,14,21,24}$ In addition to the previously mentioned morphological features, some of the published reports have included other findings that, although uncommon, can also occur in deciduoid mesotheliomas. These include the presence of focal areas in which the cells present foamy, ${ }^{18}$ vacuolated ${ }^{10,11}$ or clear cytoplasm, ${ }^{15,19}$ prominent intracytoplasmic lumina, ${ }^{3,5,15}$ focal rhabdoid changes, ${ }^{7,19}$ and mucinous or myxoid stroma. ${ }^{20}$ In general, the spectrum of morphological features of the deciduoid mesotheliomas in the present series was comparable to that described in previously reported cases. Additionally, as in previous investigations, the extent of deciduoid features in the present series varied from case to case, being focal in some, predominant in others, and on occasion, occurring in the entire tumor.

The results of the immunohistochemical studies in the reported cases of deciduoid mesothelioma are summarized in Table 5. According to these studies, deciduoid mesotheliomas commonly express calretinin, keratin 5/6, thrombomodulin, EMA, and HBME-1 and they are almost invariably negative for those markers that are not expected to be expressed in mesotheliomas, including CEA, CD15, and Ber-EP4. The present study largely confirms these observations and shows that deciduoid mesotheliomas also commonly express other markers that have more recently been recognized as mesothelioma markers, such as podoplanin, WT1, and mesothelin, thus indicating that the immunoprofile of these tumors is no different from that of other epithelioid mesothelioma variants. ${ }^{38,39}$ It was also found that, because the reactivity for podoplanin and mesothelin occurs mainly along the cell membrane, immunostaining for these markers can be very useful for enhancing the cellular pleomorphism found in some cases of deciduoid mesothelioma (Figures 3c and d). Electron microscopy frequently demonstrates the presence of ultrastructural features that are regarded as being characteristic of mesothelial differentiation, such as the presence of numerous, long, slender, branching microvilli on the apical and lateral surfaces of the cell membrane. ${ }^{40,41}$ It also shows that the glassy appearance observed in the cytoplasm on light microscopy is because of the presence of large amounts of intermediate filaments, which can occur either in a dispersed form or arranged in bundles. ${ }^{5,15}$ Additionally, electron microscopy confirms that the nuclear pseudoinclusions that are often seen in some cases of deciduoid mesothelioma represent a portion of the cytoplasm that has protruded into the nucleus while the nuclear membrane remains intact.

Although mesotheliomas with deciduoid features are uncommon, it is important for pathologists to be aware of this morphological variant of epithelioid mesothelioma as it can, on occasion, pose diagnostic difficulties, as is shown by the fact that some of the reported cases were initially misdiagnosed as either pseudotumoral deciduosis ${ }^{2,21}$ or rhabdomyosarcoma. ${ }^{3}$ Deciduoid mesotheliomas involving the peritoneum of women should be distinguished from pseudotumoral deciduosis, a condition that, although more frequently associated with pregnancy, ${ }^{42}$ can be idiopathic, ${ }^{43}$ and has been reported

Figure 2 Case 7. (a) An area in which the neoplastic cells with deciduoid features exhibits a marked loss of cellular cohesion. The nuclei of the cells in the left upper corner are more pleomorphic and hyperchromatic. (b) Adjacent area to that shown in the previous photomicrograph in which the cells appear more pleomorphic, while still retaining some deciduoid features. A mitotic figure can be seen both in the lower left and lower right corners. (c) In this area of the same case, the cells exhibit prominent rhabdoid features. Case 21. (d) Low magnification in which most of the neoplastic cells have intracytoplasmic lumina. (e) Higher magnification of an adjacent area to better demonstrates the deciduoid morphology of the neoplastic cells. The intracytoplasmic lumina appear empty. (f) Area of the tumor in which some of the intracytoplasmic lumina contain granular, bluish material that is most probably proteoglycans. Case 12. (g) Lower power magnification of a deciduoid mesothelioma with prominent myxoid stroma. (h) Higher magnification showing the deciduoid features of the tumor. 


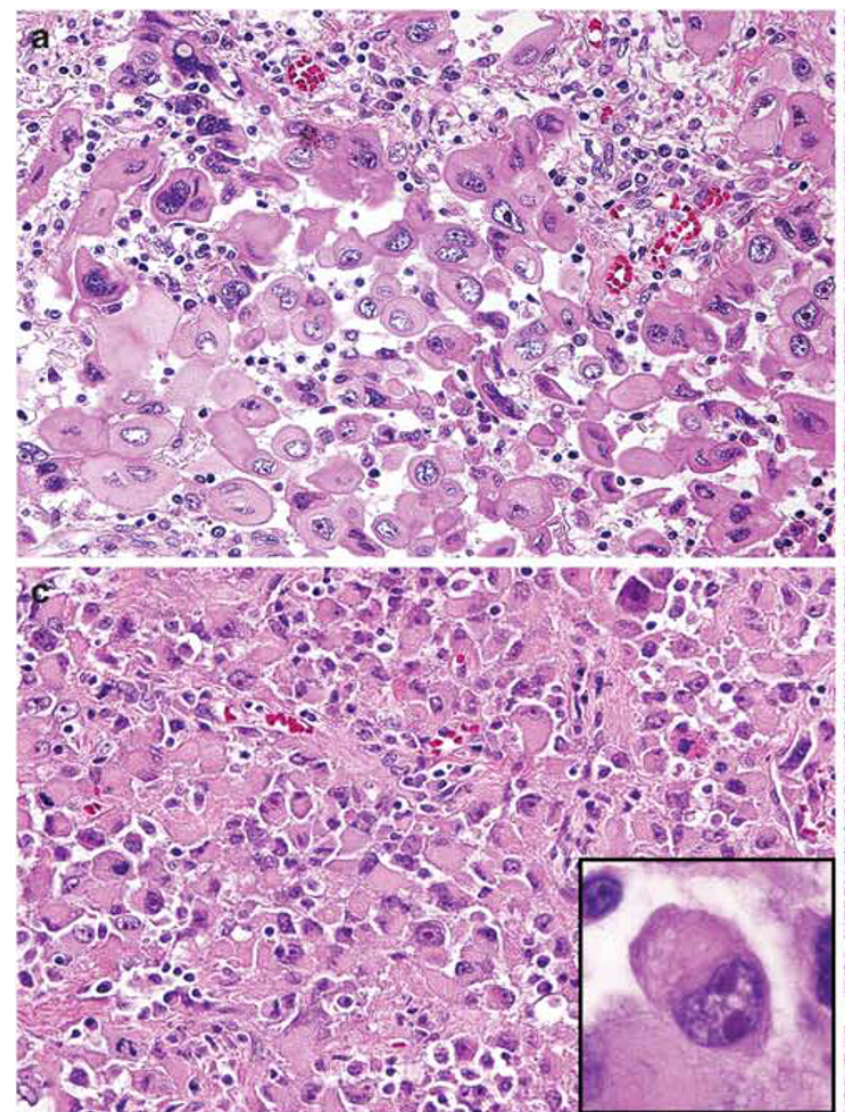

a. 0 -

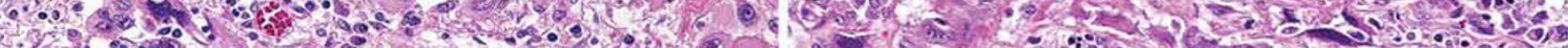

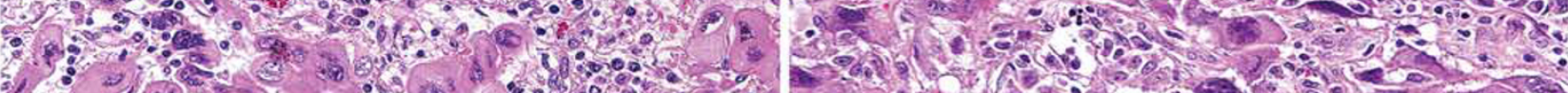

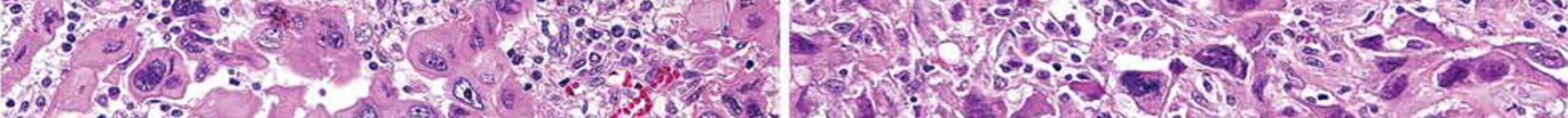

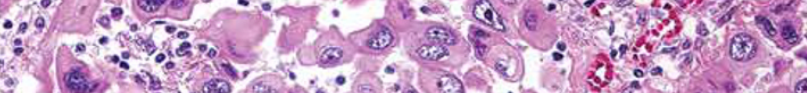

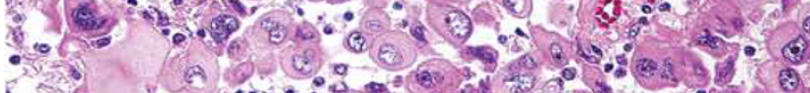

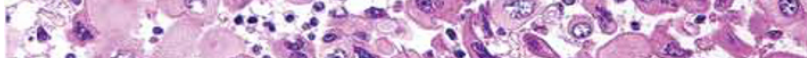
Fon - 194 .

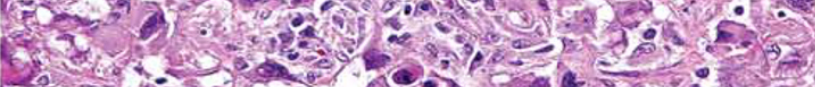

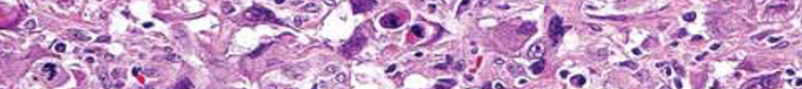

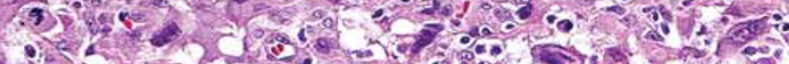

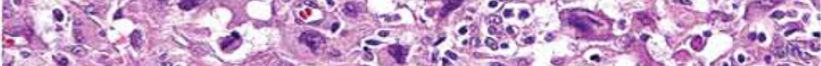
503 (2)

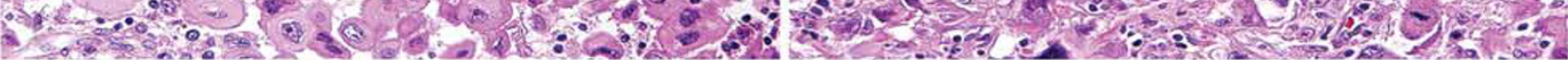
c5.

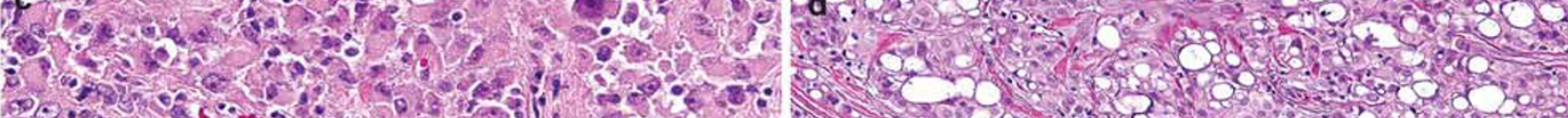

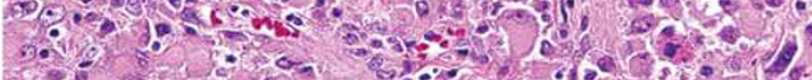

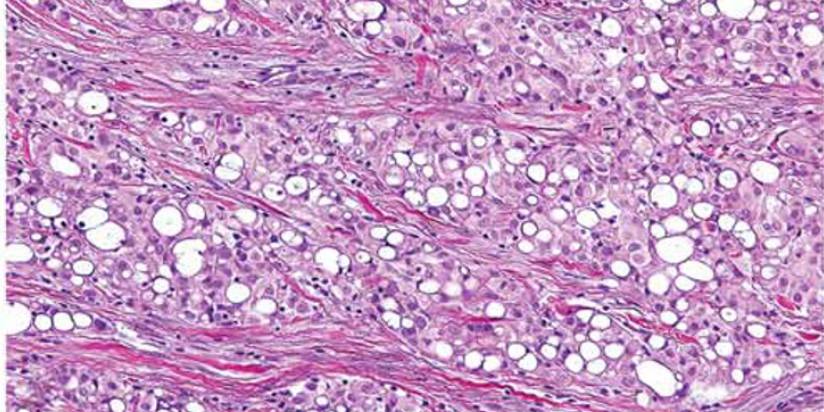

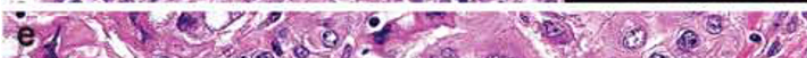

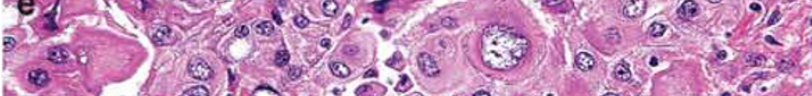

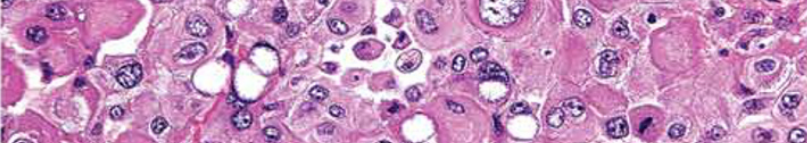

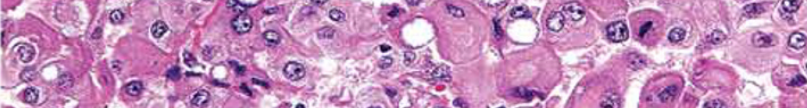

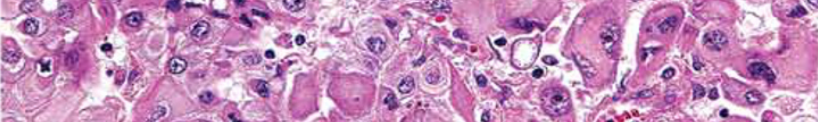

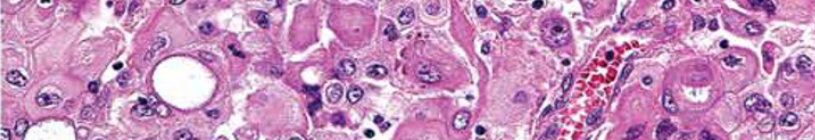

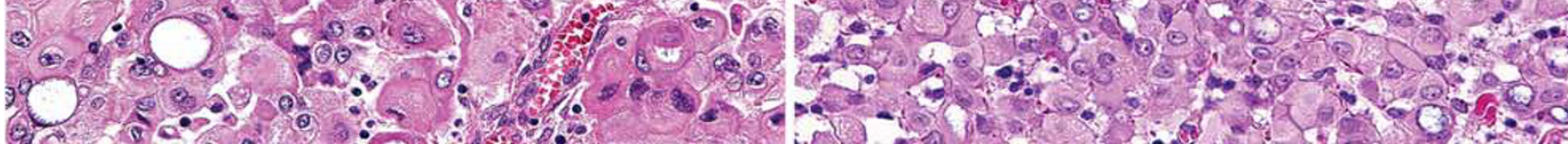

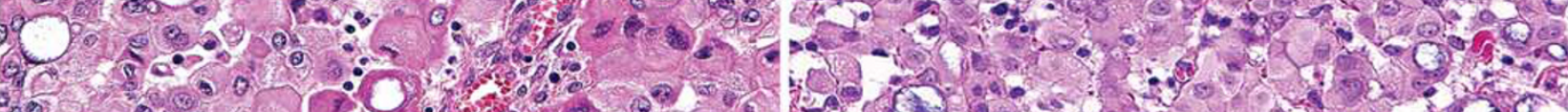

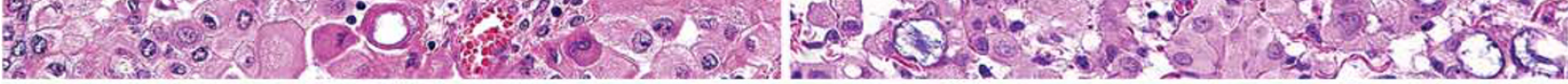

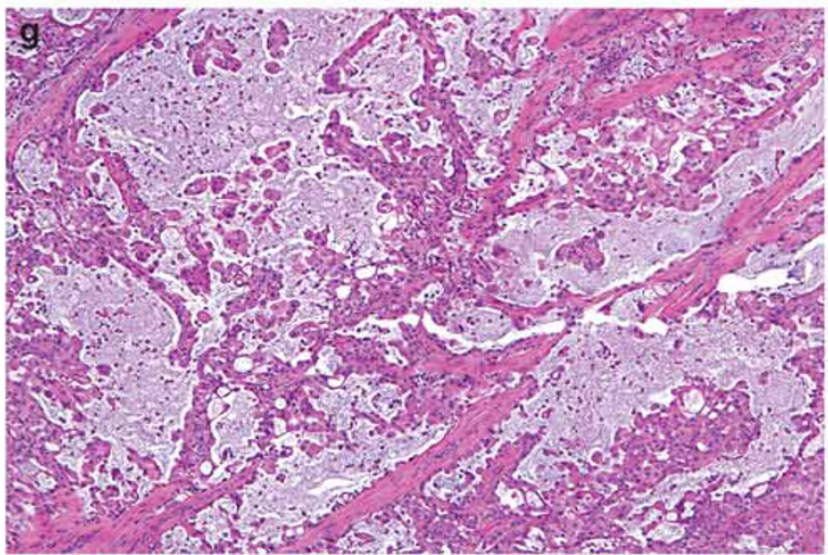
6.5. 17 .

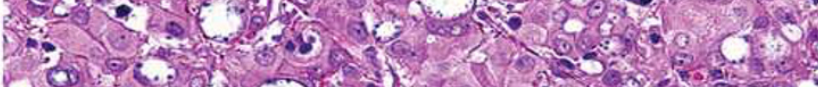

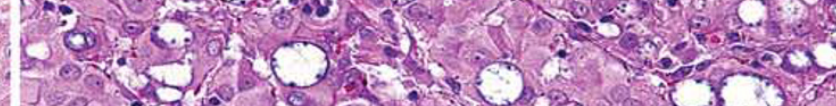

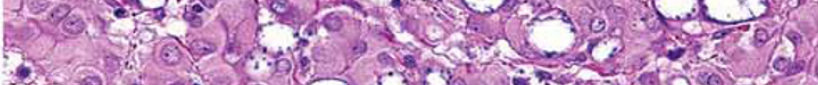

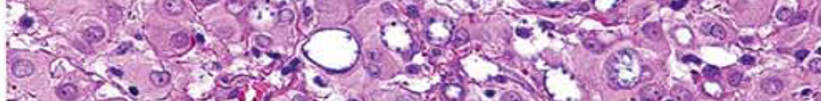

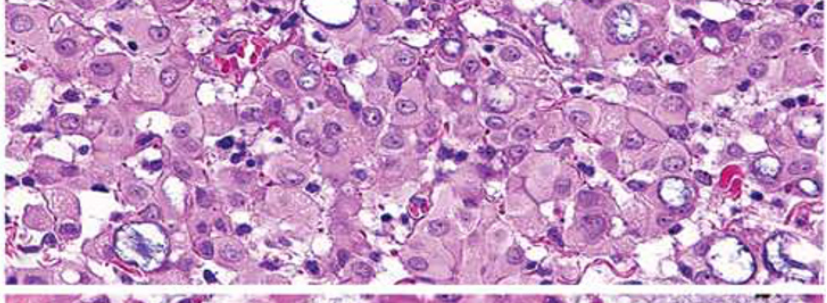

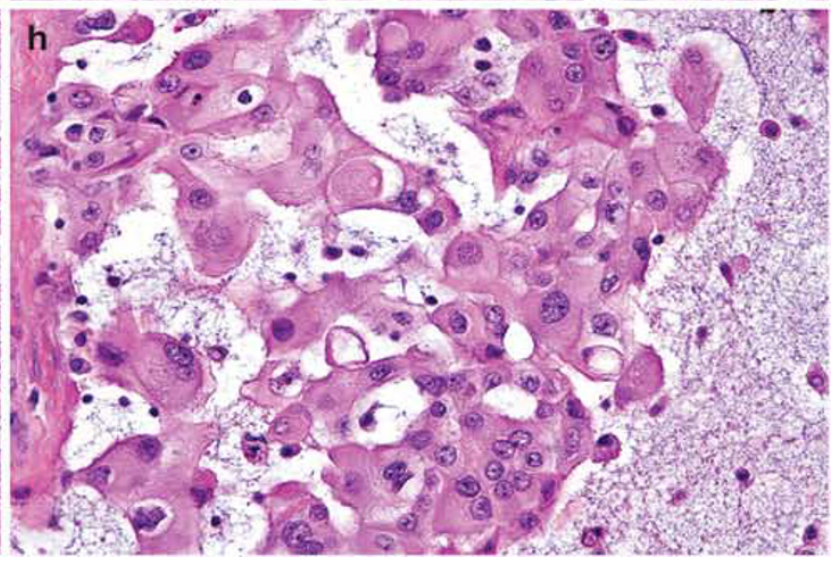




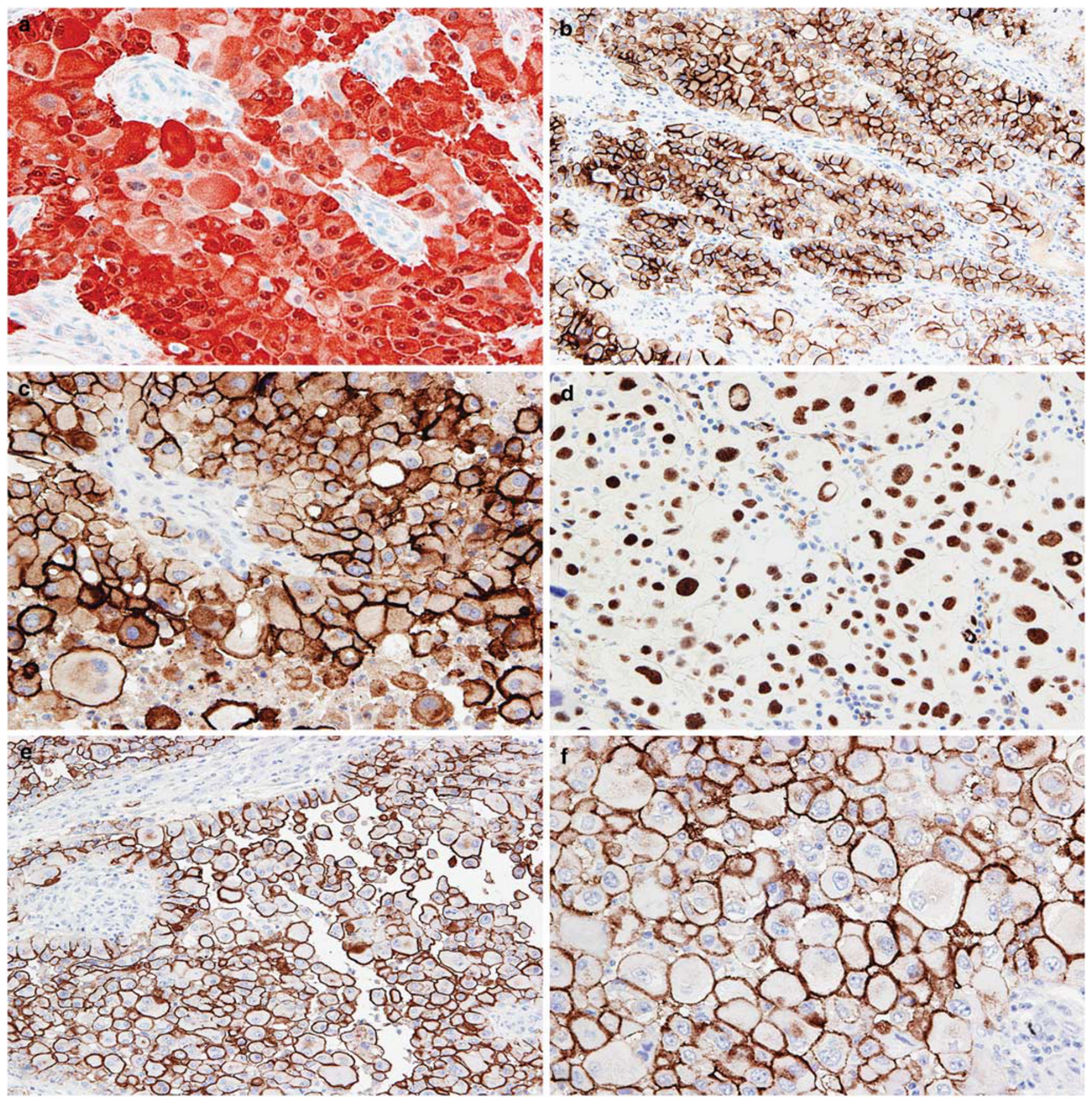

Figure 3 Case 1. (a) Immunohistochemical preparation showing strong nuclear and cytoplasmic positivity for calretinin. (b) Diffuse strong membranous positivity for mesothelin. (c) Higher magnification of the same preparation to better demonstrate the marked pleomorphism of the neoplastic cells. (d) The nuclei of the neoplastic cells are markedly pleomorphic and strongly positive for WT1. The clear areas seen in some of the nuclei (upper center) are most probably because of the presence of pseudonuclear inclusions. (e) Immunohistochemical preparation showing strong reactivity for podoplanin. Notice that the immunoreaction in the most cohesive cells, which are located at the periphery, is usually confined to the apical and lateral cell membrane, while the staining of the less cohesive cells occurs in the entire cell membrane. (f) Higher magnification of the same preparation in which the staining enhances the pleomorphism and marked variation in size of the neoplastic cells.

Figure 4 (a) Low power magnification electron micrograph in which the neoplastic cells remain barely attached by a few poorly developed junctions. The nuclei of both the cells in the center of the figure are moderately irregular and contain a single (right) or multiple (left) large nucleoli. (b) Detached multinucleated tumor cell in which the entire surface of the cell membrane is covered by microvilli. (c) A neoplastic cell with a markedly irregular nucleus containing a nuclear pseudoinclusion that is composed of cytoplasm showing partially degenerated organelles. The cell membrane appears to be covered by numerous microvilli. (d) Portion of a neoplastic cell showing numerous bundles of intermediate filaments located mainly in the paranuclear area. (e) Neoplastic cell showing intracytoplasmic lumina. The cell membrane that borders the intracytoplasmic lumina is covered by numerous, long, slender microvilli. (f) Neoplastic cell with intracytoplasmic lumen containing electon-dense material that probably represents proteoglycans. ((a). $\times 2000 ;$ (b). $\times 2000 ;$ (c). $\times 2000 ;($ d). $\times 8500 ;($ e). $\times 7000 ;($ f). $\times 6000)$. 
to occur in post-menopausal women. ${ }^{44}$ It should also be mentioned that a deciduoid mesothelioma has been reported in a pregnant woman, ${ }^{18}$ as well as in a woman 6 months after a caesarean section who was originally diagnosed as having pseudotumoral deciduosis. ${ }^{21}$ In those instances in which the differential diagnosis is between deciduoid mesothelioma and pseudotumoral deciduosis, the higher
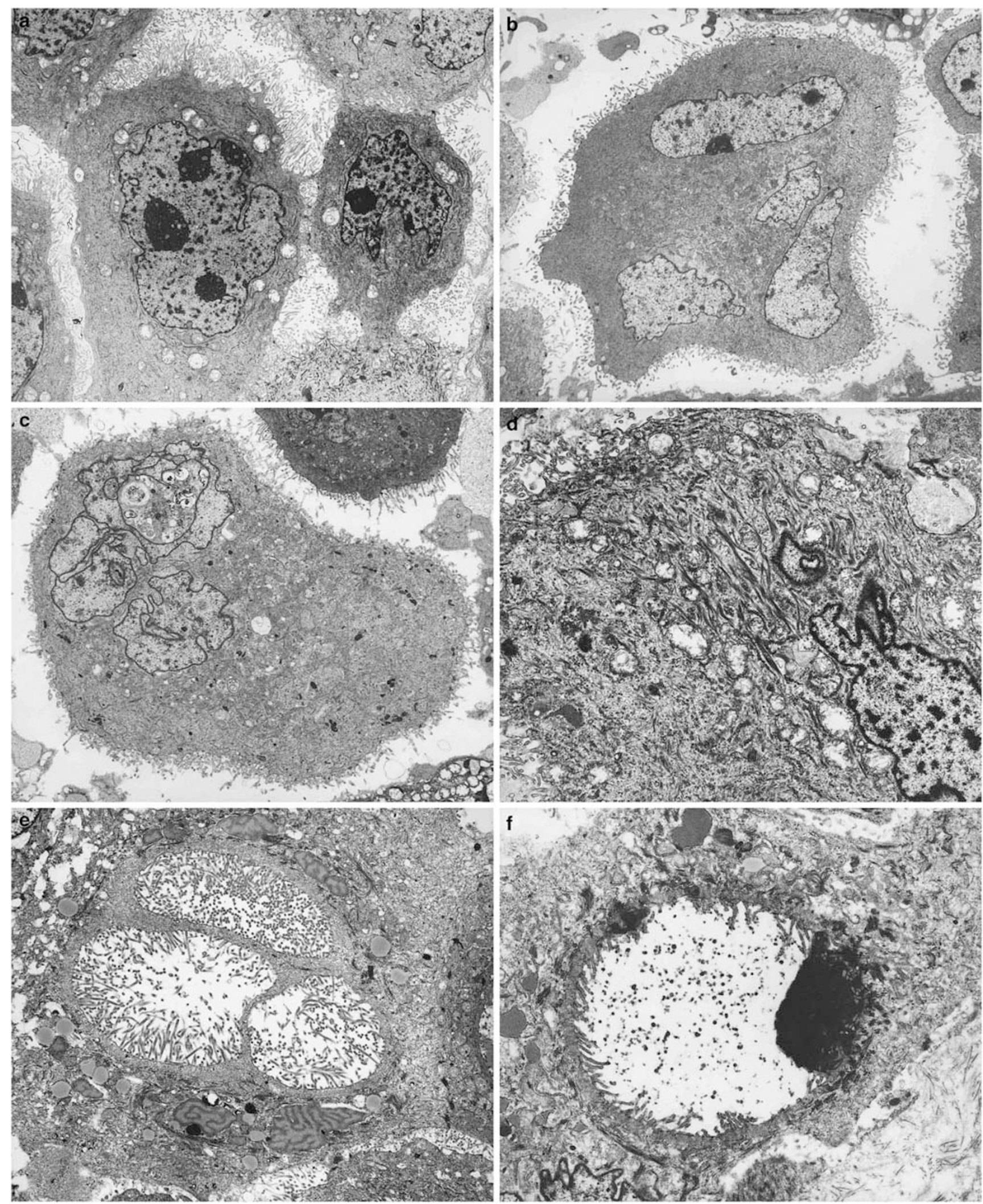
Table 4 Immunohistochemical results

\begin{tabular}{lcccccc}
\hline \multirow{2}{*}{ Marker } & $\mathrm{n}$ & + Cases $(\%)$ & \multicolumn{3}{c}{ Grade of reactivity } \\
\cline { 4 - 7 } & & & $1+$ & $2+$ & $3+$ & $4+$ \\
\cline { 4 - 7 } & & & & & & \\
\hline Calretinin & 21 & $21(100)$ & 0 & 1 & 5 & 15 \\
Pan-keratin & 16 & $16(100)$ & 0 & 0 & 0 & 16 \\
Keratin 7 & 15 & $15(100)$ & 0 & 0 & 0 & 15 \\
Keratin 5/6 & 14 & $14(100)$ & 0 & 2 & 6 & 6 \\
Podoplanin & 14 & $13(93)$ & 1 & 2 & 4 & 6 \\
WT1 & 13 & $11(85)$ & 0 & 1 & 2 & 8 \\
Mesothelin & 8 & $8(100)$ & 0 & 0 & 2 & 6 \\
MOC-31 & 21 & $0(0)$ & 0 & 0 & 0 & 0 \\
CEA & 18 & $0(0)$ & 0 & 0 & 0 & 0 \\
TAG72 & 17 & $0(0)$ & 0 & 0 & 0 & 0 \\
CD15 & 17 & $0(0)$ & 0 & 0 & 0 & 0 \\
TTF-1 & 6 & $0(0)$ & 0 & 0 & 0 & 0 \\
HCG & 4 & $0(0)$ & 0 & 0 & 0 & 0 \\
& & & 0 & & 0 & \\
\hline
\end{tabular}

degree of cellular atypia and presence of mitoses would favor the former over the latter. Electron microscopy can also be helpful by the demonstration of features, such as numerous, long, slender microvilli that would indicate mesothelial differentiation. Immunohistochemical studies can also be useful, because decidual cells express estrogen receptor and alpha inhibin, markers that are absent in mesotheliomas. ${ }^{45-47}$ As some early immunohistochemical studies were unable to demonstrate keratin expression in deciduosis ${ }^{43}$ some investigators suggested that immunostaining for this marker could assist in distinguishing deciduoid peritoneal mesothelioma from deciduosis. ${ }^{1}$ Subsequent studies, however, demonstrate that both human decidua and extrauterine decidual reactions can be keratin positive and, therefore, keratin immunostaining has no value in discriminating between mesotheliomas with deciduoid features and deciduosis. ${ }^{46}$

Another condition that, in women, can potentially be confused with deciduoid mesothelioma is trophoblastic neoplasia. Given the fact that trophoblastic neoplasia occurs after pregnancy and as the neoplastic cells in this condition express HCG, immunohistochemistry can assist in establishing the correct diagnosis. It should be mentioned, however, that rare cases of mesotheliomas producing HCG have been documented in the literature. ${ }^{48,49}$ That all 13 of the reported cases of deciduoid mesothelioma that have been investigated for HCG expression were negative for this marker, ${ }^{1,6,8,11,18,21}$ as were the 4 additional cases in the present study, is an indication that if HCG is expressed in deciduoid mesotheliomas, it would be extremely rare.

Deciduoid mesotheliomas also need to be distinguished from a variety of other neoplastic conditions that are characterized by the presence of large cells with abundant eosinophilic cytoplasm, such as oxyphilic clear cell renal cell carcinomas, and some anaplastic carcinomas that frequently contain multinucleated cells, such as pleomorphic lung carcinomas. PAX 8 is a marker that is commonly expressed in renal
Table 5 Summary of immunohistochemical findings reported in published cases of deciduoid mesothelioma

\begin{tabular}{lccl}
\hline Marker & $\mathrm{n}$ & +Cases $(\%)$ & \multicolumn{1}{c}{ References } \\
\hline Calretinin & 27 & $27(100)$ & $3,5-7,10-18,21-24$ \\
Pan-keratin & 29 & $29(100)$ & $1-4,6-15,18,20,21,23,24$ \\
Keratin 5/6 & 15 & $15(100)$ & $4,5,11,18,21,23,24$ \\
Keratin 7 & 2 & $1(50)$ & 17,24 \\
Keratin 8 & 11 & $11(100)$ & $1,3,9,10,12,15$ \\
CAM 5.2) & & & \\
Keratin 20 & 1 & $0(0)$ & 24 \\
EMA & 14 & $13(93)$ & $6,8,9,12,14,19,22$ \\
Vimentin & 30 & $26(87)$ & $1-4,6,7,10,13,15,17,18,20-22,24$ \\
Thrombomodulin & 10 & $9(90)$ & $4,5,12,18$ \\
HBME-1 & 12 & $12(100)$ & $4,8,14,18,23,24$ \\
Ber-EP4 & 16 & $1^{\text {a }}(6)$ & $3,4,7,8,12,15,18,23$ \\
Carcinoembryonic & 27 & $1^{\text {b }}(4)$ & $1,3-5,7-10,12,13,15,18,20,24$ \\
antigen & & & \\
CD15 & 27 & $2^{\text {a }}(7)$ & $1,3-5,7,9,10,12-15,21,23$ \\
Desmin & 8 & $0(0)$ & $1,2,8,14,18,21$ \\
Muscle-specific actin & 2 & $0(0)$ & 1 \\
Smooth muscle actin & 13 & $3^{\mathrm{a}}(23)$ & $4,14,17,18,21,23,24$ \\
HCG & 13 & $0(0)$ & $1,6,8,11,15,16,18,21$ \\
S100 protein & 13 & $0(0)$ & $1,4,8,9,14,23$ \\
Estrogen receptor & 8 & $0(0)$ & $1,6,9,12,14,18$ \\
Progesterone receptor & 7 & $0(0)$ & $1,6,12,14,18$ \\
CD34 & 2 & $0(0)$ & 18,24 \\
PLAP & 1 & $0(0)$ & 8 \\
CD117 (c-kit) & 1 & $0(0)$ & 24 \\
& & & \\
& &
\end{tabular}

Abbreviations: EMA, epithelial membrane antigen; PLAP, placental alkaline phosphatase.

${ }^{\mathrm{a}}$ Focal areas.

${ }^{\mathrm{b}}$ Scattered cells.

cell carcinomas, ${ }^{50-52}$ but usually absent in mesotheliomas; ${ }^{53}$ therefore, immunostaining for this marker can assist in distinguishing between deciduoid mesothelioma and renal cell carcinomas. In my experience, pleomorphic carcinomas of the lung, in contrast to deciduoid mesotheliomas, do not express calretinin, mesothelin, or WT1, therefore, immunostaining for these markers can assist in discriminating between these two malignancies. TTF-1, which is invariably absent in mesotheliomas, has been reported to be expressed in about $50 \%$ of pleomorphic lung carcinomas; ${ }^{54}$ therefore, when immunoreactivity for this marker is present, it may help to establish the lung origin of a pleomorphic carcinoma involving the pleura. Additionally, some non-epithelial tumors, such as gastrointestinal stromal tumors, rhabdomyosarcomas, and melanomas, can on occasion resemble deciduoid mesothelioma. When these tumors are included in the differential diagnosis, immunostaining for CD117 (c-kit), myogenin, and melanoma markers, such as melan A or HMB-45, that are commonly expressed in gastrointestinal stromal tumors, rhabdomyosarcomas, and melanomas, respectively, but absent in mesotheliomas, can assist in distinguishing between these malignancies and deciduoid mesothelioma.

Controversy exists in the literature regarding the prognosis of patients with deciduoid mesothelioma. Although in early studies it was emphasized that this mesothelioma variant is characterized by an aggressive clinical behavior, ${ }^{1-3}$ some subsequent 
investigations have indicated that they do not represent a category of tumors with an unfavorable prognosis nor do they behave in a manner that is clinically different from other more conventional epithelioid mesotheliomas. ${ }^{14,15}$ It should be noted that detailed information regarding the histological features of these tumors was provided in relatively few of the reported cases of deciduoid mesothelioma for which follow-up information was available (Table 1). In the five reported cases in which it was indicated that the tumor had high mitotic activity ( $>5$ mitoses per $10 \mathrm{HPF}$ ), including the presence of atypical mitoses, the patients had a shorter survival (5-11 months, mean 8); ${ }^{2,3,5}$ while in five of those cases in which it was stated that the mitotic figures were rare or uncommon $(<3$ per 10 HPF), two patients died of disease 17 and 30 months after diagnosis, respectively, ${ }^{14}$ and three were alive at the time of publication 12, 20, and 32 months after diagnosis, respectively. ${ }^{9,12,18}$ These findings are comparable to those of the present investigation in that those tumors with a high number of mitoses ( $>5$ per $10 \mathrm{HPF}$ ), a decrease in cell cohesion, highly atypical nuclei that vary in their size and often contain cytoplasmic inclusions, and large, sometimes multiple nucleoli tend to behave in a more aggressive manner than those in which the mitotic activity was low, the cells were more uniform and more cohesive, and the nuclei exhibited less atypia. In the present series, 7 of the cases (Cases 1, 2, 6, 7, 8,13 , and 15 ) that were considered to belong to the first group died of disease 4-17 months (mean, 7 months) after diagnosis, while 9 of the 10 cases (Cases 5, 12, 14, 16, 17, 18, 19, 20, and 21) that were considered to belong to the second group died of disease 6-62 months (mean, 22 months) after diagnosis and the remaining patient (Case 4) was alive 25 months following diagnosis (Table 3). These observations appear to be in agreement with a recent investigation that indicated that nuclear grading based on nuclear features and mitotic count can provide prognostic information in epithelioid diffuse malignant pleural mesothelioma. ${ }^{55}$ In that study, it was reported that patients with tumors displaying nuclear atypia, prominent nucleoli, nuclear pseudoinclusions, high mitotic count $(>5$ per $10 \mathrm{HPF}$ ), and atypical mitoses had a shorter median survival (5 months) when compared with the overall survival of all of the patients (16 months) included in their investigation. Therefore, based on the findings of the present study, as well as on those reported previously, it appears that there is a subset of deciduoid mesotheliomas that, because of their morphological features and clinical behavior, should be regarded as high-grade mesotheliomas. As, in addition to their deciduoid features, these tumors are characterized by having a relatively large number of multinucleated neoplastic cells, marked cellular pleomorphism, frequent loss of cell cohesion, and high mitotic activity, including the presence of atypical mitoses, it would be better, in my opinion, to classify deciduoid mesotheliomas with this morphology as a variant of pleomorphic mesothelioma. The morphological features of highgrade deciduoid mesothelioma not only overlap with those of epithelioid pleomorphic mesothelioma but also the prognosis of both groups is very similar, as was seen in two recent studies on pleomorphic mesotheliomas in which the median survival was reported to be 8.1 and 7.3 months, respectively. ${ }^{36,37}$ Therefore, based on the above information, the difference in prognosis that has been reported in deciduoid mesotheliomas can be explained by the fact that a subgroup of high-grade deciduoid mesotheliomas exists. Finally, it is recommended that, because high-grade deciduoid mesotheliomas are associated with highly aggressive clinical behavior, when this subtype of epithelioid mesothelioma is present, it should be indicated in the pathology report as this can significantly affect not only the prognosis but also patient treatment.

\section{Disclosure/conflict of interest}

The author declares no conflict of interest.

\section{References}

1 Nascimento AG, Keeney GL, Fletcher CD. Deciduoid peritoneal mesothelioma. An unusual phenotype affecting young females. Am J Surg Pathol 1994;18:439-445.

2 Talerman A, Montero JR, Chilcote RR, et al Diffuse malignant peritoneal mesothelioma in a 13-year-old girl. Report of a case and review of the literature. Am J Surg Pathol 1985;9:73-80.

3 Orosz Z, Nagy P, Szentirmay Z, et al Epithelial mesothelioma with deciduoid features. Virchows Arch 1999;434:263-266.

4 Shanks JH, Harris M, Banerjee SS, et al Mesotheliomas with deciduoid morphology: A morphologic spectrum and a variant not confined to young females. Am J Surg Pathol 2000;24:285-294.

5 Ordóñez NG. Epithelial mesothelioma with deciduoid features: Report of four cases. Am J Surg Pathol 2000;24:816-823.

6 Gloeckner-Hofmann $\mathrm{K}$, Zhu XZ, Bartels $\mathrm{H}$, et al Deciduoid pleural mesothelioma affecting a young female without prior asbestos exposure. Respiration 2000;67:456-458.

7 Puttagunta L, Vriend RA, Nguyen GK. Deciduoid epithelial mesothelioma of the pleura with focal rhabdoid change. Am J Surg Pathol 2000;24:1440-1443.

8 Desai S, Kane S, Bharde S, et al Malignant peritoneal mesothelioma deciduoid or anaplastic variant? Point to ponder. Indian J Pathol Microbiol 2001;44:159-162.

9 Gillespie FR, van der Walt JD, Derias N, et al Deciduoid peritoneal mesothelioma. A report of the cytological appearances. Cytopathology 2001;12:57-61.

10 Henley JD, Loehrer Sr PJ, Ulbright TM. Deciduoid mesothelioma of the pleura after radiation therapy for Hodgkin's disease presenting as a mediastinal mass. Am J Surg Pathol 2001;25:547-548.

11 Monaghan H, Al-Nafussi A. Deciduoid pleural mesothelioma. Histopathology 2001;39:104-106. 
12 Okonkwo A, Musunuri S, Diaz Jr L, et al Deciduoid mesothelioma: a rare, distinct entity with unusual features. Ann Diagn Pathol 2001;5:168-171.

13 Reis-Filho JS, Pope LZ, Milanezi F, et al Primary epithelial malignant mesothelioma of the pericardium with deciduoid features: Cytohistologic and immunohistochemical study. Diagn Cytopathol 2002;26:117-122.

14 Serio G, Scattone A, Pennella A, et al Malignant deciduoid mesothelioma of the pleura: report of two cases with long survival. Histopathology 2002; 40:348-352.

15 Shia J, Erlandson RA, Klimstra DS. Deciduoid mesothelioma: A report of 5 cases and literature review. Ultrastruct Pathol 2002;26:355-363.

16 Chung DJ, Kang YW, Kim BK, et al Deciduoid peritoneal mesothelioma: CT findings with pathologic correlation. Abdom Imaging 2003;28:614-616.

17 Asioli S, Dal Piaz G, Damiani S. Localised pleural malignant mesothelioma. Report of two cases simulating pulmonary carcinoma and review of the literature. Virchows Arch 2004;445:206-209.

18 Maeda S, Hosone M, Katayama H, et al Deciduoid mesothelioma in the pelvic cavity. Pathol Int 2004; 54:67-72.

19 Mishra A, Shet T. Clear cell mesothelioma of the testis with deciduoid areas-a case report. Indian J Pathol Microbiol 2004;47:544-546.

20 Kimura N, Ogasawara T, Asonuma S, et al Granulocyte-colony stimulating factor- and interleukin 6producing diffuse deciduoid peritoneal mesothelioma. Mod Pathol 2005;18:446-450.

21 Mourra N, de Chaisemartin C, Goubin-Versini I, et al Malignant deciduoid mesothelioma: a diagnostic challenge. Arch Pathol Lab Med 2005;129:403-406.

22 Scattone A, Pennella A, Gentile M, et al Comparative genomic hybridisation in malignant deciduoid mesothelioma. J Clin Pathol 2006;59:764-769.

23 Tsai LY, Yang YL, Lu MY, et al Deciduoid mesothelioma of the pleura in an adolescent boy. Pediatr Hematol Oncol 2010;27:132-137.

24 Ustun H, Astarci HM, Sungu N, et al Primary malignant deciduoid peritoneal mesothelioma: a report of the cytohistological and immunohistochemical appearances. Diagn Cytopathol 2011;39:402-408.

25 Miller K, Auld J, Jessup E, et al Antigen unmasking in formalin-fixed routinely processed paraffin wax-embedded sections by pressure cooking: A comparison with microwave oven heating and traditional methods. Adv Anatomic Pathol 1995;2:60-64.

26 Allen TC. Recognition of histopathologic patterns of diffuse malignant mesothelioma in differential diagnosis of pleural biopsies. Arch Pathol Lab Med 2005;129:1415-1420.

27 Cook DS, Attanoos RL, Jalloh SS, et al 'Mucin-positive' epithelial mesothelioma of the peritoneum: an unusual diagnostic pitfall. Histopathology 2000;37:33-36.

28 Rekhi B, Pathuthara S, Ajit D, et al 'Signet-ring' cellsa caveat in the diagnosis of a diffuse peritoneal mesothelioma occurring in a lady presenting with recurrent ascites: an unusual case report. Diagn Cytopathol 2010;38:435-439.

29 Ordóñez NG. Mesothelioma with rhabdoid features: an ultrastructural and immunohistochemical study of 10 cases. Mod Pathol 2006;19:373-383.

30 Ordóñez NG. Mesotheliomas with crystalloid structures: report of nine cases, including one with oncocytic features. Mod Pathol 2012;25:272-281.
31 Ordóñez NG, Myhre M, Mackay B. Clear cell mesothelioma. Ultrastruct Pathol 1996;20:331-336.

32 Ordóñez NG. Mesothelioma with clear cell features: an ultrastructural and immunohistochemical study of 20 cases. Hum Pathol 2005;36:465-473.

33 Mayall FG, Gibbs AR. The histology and immunohistochemistry of small cell mesothelioma. Histopathology 1992;20:47-51.

34 Ordóñez NG. Mesotheliomas with small cell features: Report of eight cases. Mod Pathol 2012;25:689-698.

35 Martínez-Consuegra N, Muñoz-Juárez M, Ortiz-Hidalgo C. Unusual multifocal glomeruloid pattern in a well-differentiated papillary mesothelioma of the peritoneum. Int J Surg Pathol 2008;16:426-427.

36 Kadota K, Suzuki K, Sima CS, et al Pleomorphic epithelioid diffuse malignant pleural mesothelioma: a clinicopathological review and conceptual proposal to reclassify as biphasic or sarcomatoid mesothelioma. J Thorac Oncol 2011;6:896-904.

37 Ordóñez NG. Pleomorphic mesothelioma: Report of 10 cases. Mod Pathol; advance online publication, 2 March 2012 [e-pub ahead of print].

38 Ordóñez NG. The immunohistochemical diagnosis of mesothelioma: a comparative study of epithelioid mesothelioma and lung adenocarcinoma. Am J Surg Pathol 2003;27:1031-1051.

39 Ordóñez NG. What are the current best immunohistochemical markers for the diagnosis of epithelioid mesothelioma? A review and update. Hum Pathol 2007;38:1-16.

40 Ordóñez NG, Mackay B. The roles of immunohistochemistry and electron microscopy in distinguishing epithelial mesothelioma of the pleura from adenocarcinoma. Adv Anat Pathol 1996;3:273-293.

41 Ordóñez NG. The diagnostic utility of immunohistochemistry and electron microscopy in distinguishing between peritoneal mesotheliomas and serous carcinomas: a comparative study. Mod Pathol 2006;19:34-48.

42 Zaytsev P, Taxy JB. Pregnancy-associated ectopic decidua. Am J Surg Pathol 1987;11:526-530.

43 Suster S, Moran CA. Deciduosis of the appendix. Am J Gastroenterol 1990;85:841-845.

44 Clement PB, Scully RE. Idiopathic postmenopausal decidual reaction of the endometrium. A clinicopathologic analysis of four cases. Int J Gynecol Pathol 1988;7:152-161.

45 Petraglia F, Calzà L, Garuti GC, et al Presence and synthesis of inhibin subunits in human decidua. J Clin Endocrinol Metab 1990;71:487-492.

46 Heatley MK, Maxwell P, Toner PG. The immunophenotype of human decidua and extra-uterine decidual reactions. Histopathology 1996;29:437-442.

47 Ordóñez NG. Value of estrogen and progesterone receptor immunostaining in distinguishing between peritoneal mesotheliomas and serous carcinomas. Hum Pathol 2005;36:1163-1167.

48 Rich S, Presant CA, Meyer J, et al Human chorionic gonadotropin and malignant mesothelioma. Cancer 1979;43:1457-1462.

49 Okamoto H, Matsuno Y, Noguchi M, et al Malignant pleural mesothelioma producing human chorionic gonadotropin. Report of two cases. Am J Surg Pathol 1992;16:969-974.

50 Tong GX, Yu WM, Beaubier NT, et al Expression of PAX8 in normal and neoplastic renal tissues: an immunohistochemical study. Mod Pathol 2009;22: 1218-1227. 
51 Ozcan A, Shen SS, Hamilton C, et al PAX 8 expression in non-neoplastic tissues, primary tumors, and metastatic tumors: a comprehensive immunohistochemical study. Mod Pathol 2011;24:751-764.

52 Sangoi AR, Fujiwara M, West RB, et al Immunohistochemical distinction of primary adrenal cortical lesions from metastatic clear cell renal cell carcinoma: a study of 248 cases. Am J Surg Pathol 2011;35:678-686.

53 Laury AR, Hornick JL, Perets R, et al PAX8 reliably distinguishes ovarian serous tumors from malignant mesothelioma. Am J Surg Pathol 2010; 34:627-635.

54 Rossi G, Cavazza A, Sturm N, et al Pulmonary carcinomas with pleomorphic, sarcomatoid, or sarcomatous elements: a clinicopathologic and immunohistochemical study of 75 cases. Am J Surg Pathol 2003;27:311-324.

55 Kadota K, Suzuki K, Colovos C, et al A nuclear grading system is a strong predictor of survival in epitheloid diffuse malignant pleural mesothelioma. Mod Pathol 2012;25:260-271. 